\title{
Giorgio Vasari’s Mercury: God of Magic and Wisdom*
}

\author{
Liana De Girolami Cheney \\ Universidad de Coruña, Galicia, Spain
}

\begin{abstract}
In 1555, assisted by Cristofano Gherardi, Il Doceno (1508-1556), Giorgio Vasari (1511-1574) designed and painted a mythological and cosmological theme in the Sala degli Elementi, an apartment of Cosimo I de' Medici (1519-1574), Duke of Florence, at the Palazzo Vecchio in Florence. The Apartment of the Elements is dedicated to the four elements (air, earth, fire, and water), which in antiquity were considered to be the basis of the material of the world. The four elements are personified as a history painting theme on the ceiling and the walls of the chamber. Accordingly, on the ceiling is the element of Air, personified by several events: Its center depicts Saturn Mutilating Heaven and surrounding this scene are The Chariots of the Sun and the Moon, the images of Day and Night, and the virtues of Peace, Fame, Justice, and Truth. On the walls of the chamber, there are personifications of the elements of Earth (north), Fire (east), and Water (south). The frescoes on the left hand wall relate to the element of Earth. In the center of the north wall, the first fruits of the Earth are offered to Saturn. ${ }^{1}$ On the adjacent wall, east wall, above the fireplace, are scenes relating to the element of Fire: Vulcan's Forge is depicted in the center of wall. ${ }^{2}$ On the adjacent wall, south wall, the element of Water is symbolized with The Birth of Venus. ${ }^{3}$ On the window wall, west wall, are two large niches containing simulated sculptures of Hermes-Mercury and Hades-Pluto. These two images connect thematically with the wall decoration of the elements and the pantheon of the gods on the ceiling. This essay will focus only on the image of Hermes-Mercury. It consists of two parts: the stylistic impact of classical and Renaissance sources of this astral and pagan god in Vasari's imagery, and the signification of the personification of Mercury associated and interconnected with Cosimo I de’ Medici, Duke of Florence.
\end{abstract}

Keywords: Hermes/Mercury, Hades/Pluto, mythology, astrology, symbolism, Palazzo Vecchio, Sala degli Elementi, classical and Renaissance traditions, tarot cards, Neoplatonism, history painting

\footnotetext{
* This study is part of a long project and a book on Giorgio Vasari's The Sala degli Elementi: Alchemy and Symbolism (Cambridge, UK: Cambridge Scholar Publishing, forthcoming). See Liana De Girolami Cheney, "Giorgio Vasari's Vulcan's Forge, Sala degli Elementi in the Palazzo Vecchio: The Symbolism of Fire," Iconocrazia (Spring 2015), http://www.iconocrazia.it/giorgio-vasaris/; Liana De Girolami Cheney, “Giorgio Vasari’s "Sala degli Elementi” in Palazzo Vecchio, Florence: The Symbolism of Saturn as Heavenly Air,” in Heavenly Discourses, ed. Nicholas Campion (Bristol, UK: Sophia Centre Press, 2015), 14-24; Liana De Girolami Cheney, “Giorgio Vasari’s Neptune as Cosimo I de’ Medici: The Element of Water as a Political Symbol," in The Iconography of Water, ed. Pilar Diez del Coral (Lisbon: University of Lisbon, CHAM, 2019, forthcoming); and Liana De Girolami Cheney, “Giorgio Vasari’s Sala degli Elementi: The Symbolism of Water,” in Discovery (2009), 1-10. Oral presentations: "Giorgio Vasari’s "The Symbolism of Saturn in Giorgio Vasari’s Sala degli Elementi in Palazzo Vecchio, Florence,” International Conference on Crypto-pagan symbols and hidden themes, Università Cattolica di Sacro Cuore, Milan, December 15-17, 2017; Liana De Girolami Cheney, “Giorgio Vasari’s Element of Earth,” Renaissance Society of America, Montreal, Canada, April 5-10, 2011; and Liana De Girolami Cheney, "Giorgio Vasari: Sala degli Elementi," Sixteenth Century Studies International Conference, Geneva, Switzerland, May 28-31, 2009.

Liana De Girolami Cheney, PhD an Investigadora de Historia del Arte, SIEALE, Universidad de Coruña, Spain.

1 Two oval images with themes of cultivation, Triptolemus Ploughing and The Sacrifice to Cybele, frame the central scene.

2 This scene is framed by two ovals containing the stories of Vulcan Surprising Mars and Daedalus Forging Achilles' Arms.

3 Also framed by two ovals with the stories of The Offerings to Venus and Venus and Adonis.
} 


\section{Introduction}

We have an entire sky within us, our fiery strength and heavenly origin: Luna, which symbolizes the continuous motion of soul and body, Mars speed and Saturn slowness, the Sun God, Jupiter law, Mercury reason, and Venus humanity.

--Marsilio Ficino, Letter to Lorenzo the Magnificent ${ }^{4}$

Vasari created mythological paintings for private and public decorative cycles. He appropriated classical and emblematic imagery in his mythological paintings as well as fusing the humanistic and cultural pursuits of the 16th century. Elaboration on these issues focuses as well on Vasari's fascination with the antique and his role in the redefinition of history paintings or mythological paintings in the development of new formal conventions for secular decorative cycles. Vasari was anticipating the thematic conceits visualized by painters and employed by art critics in the 17th, 18th, and, in particular, early 19th centuries when referring to paintings depicting themes from classical history, mythology, secular literature, and Biblical subjects, which emphasized subject matter rather than style in a painting (Barlow, 2005).

Scholars have investigated the many important artistic and art historical facets associated with the mythological paintings of Giorgio Vasari (Rubin, 1995; Muccini \& Cecchi, 1991; Allegri \& Cecchi, 1980). Here, the focus is on an examination of his artistic achievements as a mythographer and emblematist depicting on a wall specific personifications of Mercury and Pluto in the Sala degli Elementi in Palazzo Vecchio in Florence (see Figures 1 and 2).

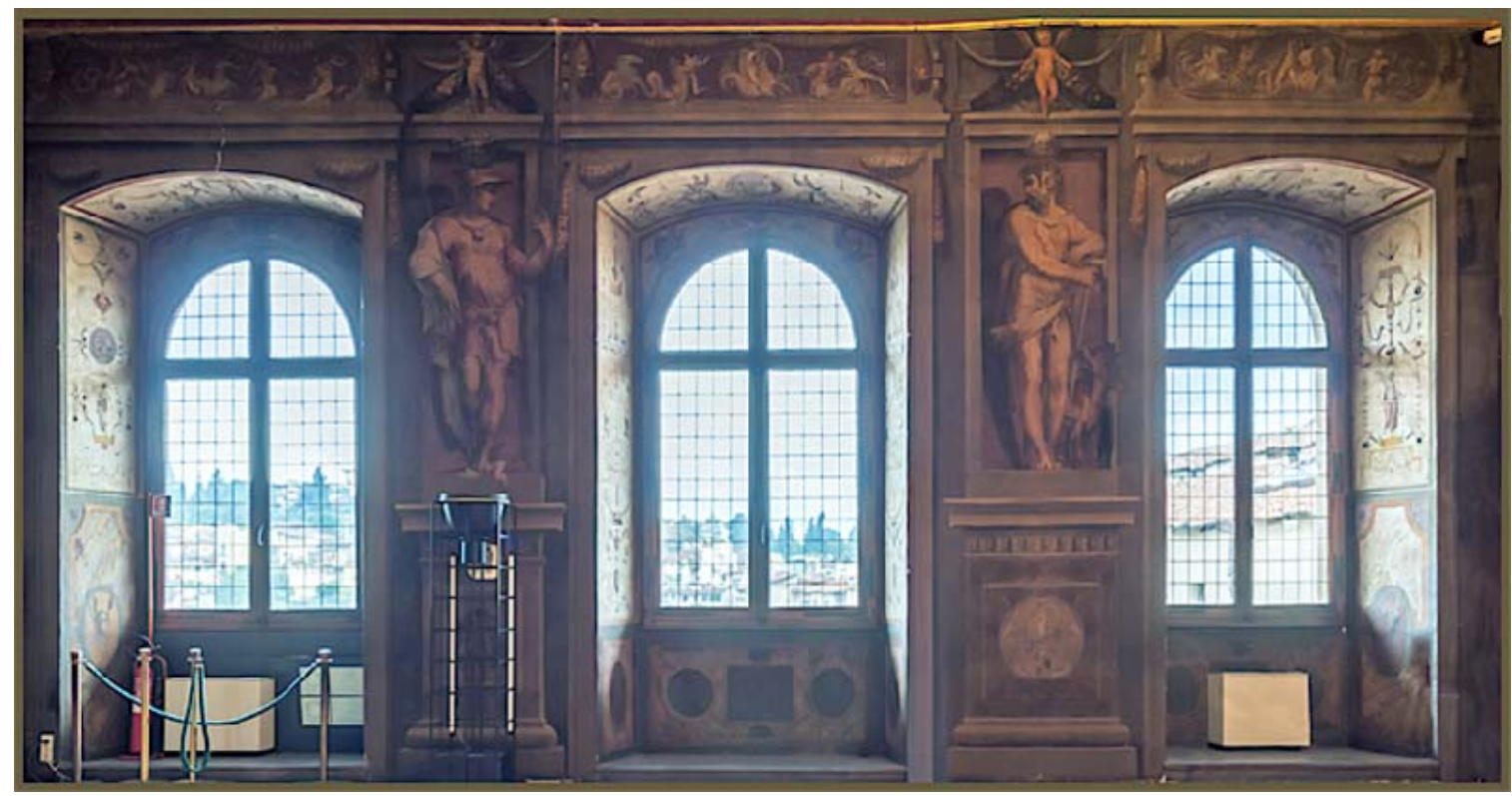

Figure 1. Giorgio Vasari and Cristofano Gherardi, Mercury and Pluto, 1555-1557.

Sala degli Elementi, Palazzo Vecchio, Florence.

Photo credit: author.

\footnotetext{
${ }^{4}$ See Thomas Moore, The Planets Within: The Astrological Psychology of Marsilio Ficino (Hudson, NY: Lindisfarne Press, 1990), p. v.
} 

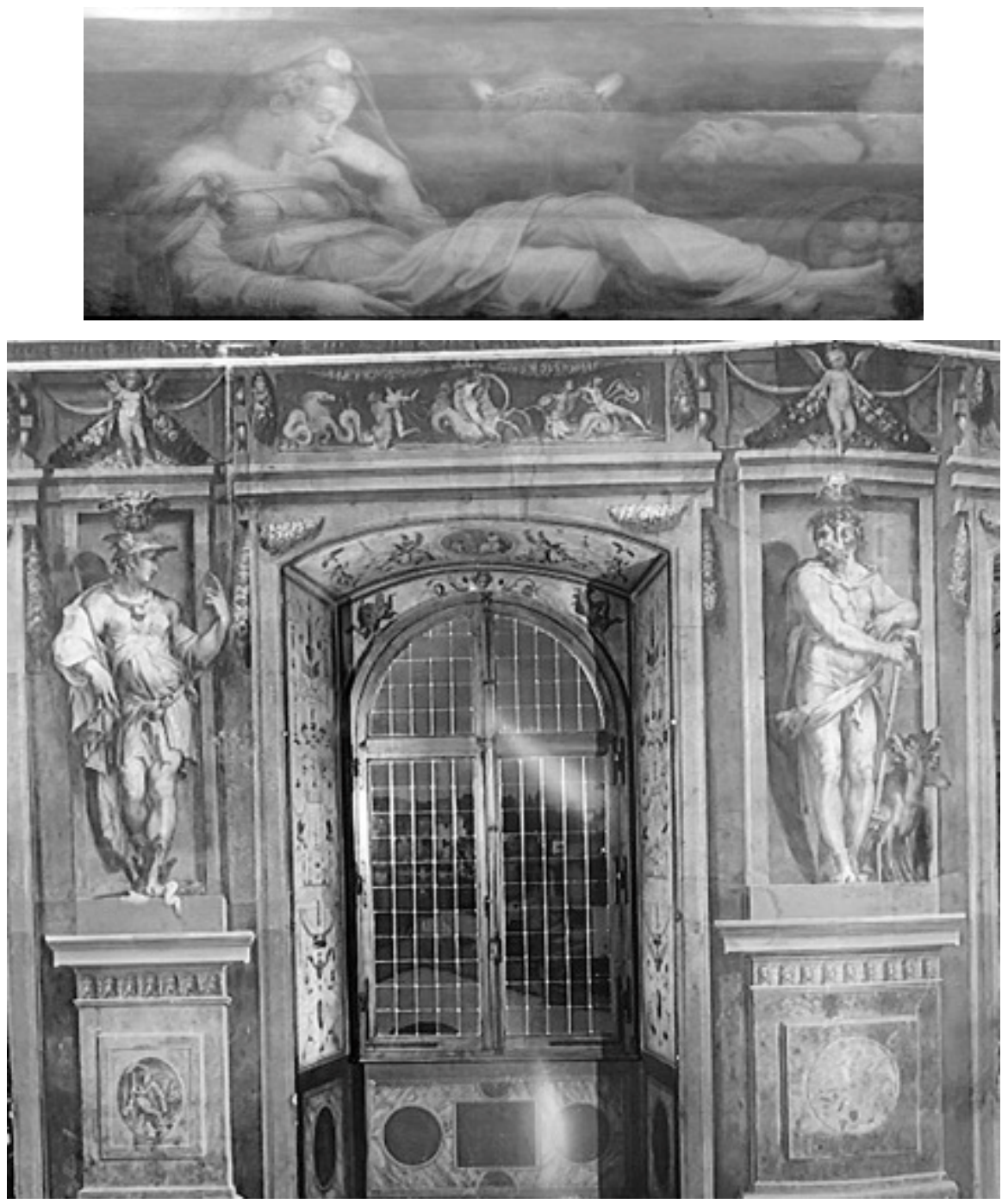

Figure 2. Giorgio Vasari and Cristofano Gherardi, 1555-1557, window wall and ceiling. Sala degli Elementi, Palazzo Vecchio, Florence.

Photo credit: author's reconstruction.

During the Cinquecento, artists consulted emblematic and mythological manuals as a source for their visual conceits. These manuals had a moral overtone and contained verbal and visual representations of the virtues, vices, passions, and temperaments, as well revealing roots in Neoplatonic philosophy (Praz, 1947/1964; Russell, 1981, p. 549). ${ }^{5}$ The most important manuals then available were Andrea Alciato's Emblemata or Emblematum Libellus (first published in 1531); Vincenzo Cartari’s Imagini delli Dei de gl' Antichi (1556); Natale Conti’s Mythologiae (1551); Lilio Gregorio Giraldi’s De Deis Gentium (1548); Francesco Colonna’s Hypnerotomachia Poliphili (1499); Horapollo's Hieroglyphica (1505); Pierio Valeriano's Hieroglyphica (1556); and Paolo Giovio's Dialogo dell'Imprese Militari et Amorose (1556) (Praz, 1947/1964, 2014; Bolzoni

\footnotetext{
${ }^{5}$ Russell defined the importance of Andrea Alciato’s book in Cinquecento art and literature: “(It) served as a manual to train readers in a particular approach to artistic artifacts. It taught them to participate actively in the moralizing of visual art, and it showed them how to fragment texts-mainly poetic or dramatic texts, it would appear-into short passages that they could summarize into titular paroemia”.
} 
\& Volterrani, 2008; Chastel, 1975; Seznec, 1972). ${ }^{6}$ These emblematic and mythographic texts were compilations of ancient and medieval mythographies, hieroglyphs, and numismatic sources containing traditional moral overtones derived from ancient and medieval philosophical sources. They served as manuals and recipe books for Cinquecento (the 16th century) humanists and artists—a kind of figurative encyclopedia or "dictionary-album for easy consultation when time was lacking to read text and reference in their entirety" (Ripa, 1593, 1603, 1971; Stefani, 1990, pp. 307-312; Gabriele, Galassi, \& Guerrini, 2013; Maffei, 2009; Cheney, 2011a, pp. 567-301). ${ }^{7}$ Since these manuals were well-known to the 16th century artists and literati, they would freely borrow or copy information directly from them without acknowledging the original source (Ripa, 1971; Praz, 1947/1964). In his writings and art, Vasari, too, appropriated visual, political, and moral concepts from these manuals in order to compose his history paintings in the decorative cycles.

In his mythical emblematic paintings as well as in his writings, Vite and I Ragionamenti (Vasari, 1550, 1568, 1588; Bettarini \& Barocchi, 1971/1986; Draper, 1973; Le Mollé \& Canfora, 2007; Baxter, 1985; Tinagli, 2000, 2001; Passignat, 2007, 2009a), Vasari relied on classical sources, both visually and intellectually, revealing the influence of ancient writers, such as Publius Ovidius Naso (Ovid, 43 BCE-17/18 CE), Gaius Plinius Secundus (Pliny the Elder, 23-79 CE), and Marcus Vitruvius (80-70 BCE-15 CE), as well as Renaissance writers, such as Leon Battista Alberti (1414-1472), Giovanni Battista Adriani (1513-1579), Vincenzo Borghini (1515-1580), Annibale Caro (1507-1566), and Paolo Giovio (1483-1552). Vasari’s assimilation of the classical tradition in mythological paintings derived from his education in classical studies as well as from his fascination with emblematic and mythographic sources, as noted earlier, viz.: Andrea Alciato (1492-1550), Vincenzo Cartari (1502-1569), and Pierio Valeriano (1447-1558) (Cheney, 2007), his artistic theory is based on the Renaissance Neoplatonic philosophy of Marsilio Ficino (1433-1499) (Cheney, 2007; Chastel, 1975).

Moreover, in 1558, while writing I Ragionamenti, Vasari sought counsel from several humanists friends, all of whom were connected to the Medicean court of Cosimo I de' Medici, Duke of Florence, including Cosimo Bartoli, a scholar on Boccaccio and Dante who had written I Ragionamenti accademici, a critical commentary on Dante (Bartoli, 1567; Cecchi, 2011; Kliemann, 1978; Bryce, 1983), ${ }^{8}$ and instructed Vasari on the new Italian translation of Boccaccio's Genealogie decorum gentilium (Della geneologia de degli Dei). ${ }^{9}$ Vincenzo Borghini, a philologist, grammarian, and historian as well as "spedalingo" (rector) of the Hospital of the Innocent, iconographically formulated most of the decorative cycles painted by Vasari in the Palazzo Vecchio. Giovanni Battista Adriani, a humanist, rhetorician, and writer, was commissioned by Cosimo I de' Medici to write a history of Florence (Istoria dei suoi Tempi) as a continuation of Francesco Guicciardini's historical view (Mazzuchelli, 1753/1760; Rubin, 1995). Adriani’s knowledge of antiquity contributed to Vasari's Vite with an explanatory letter on the history of ancient art (Cheney, 2012a). ${ }^{10}$ These Cinquecento humanists and friends wrote extensive letters to Vasari projecting the iconographical program for many rooms

\footnotetext{
${ }^{6}$ Seznec noted that "These mentioned manuscripts include antique mythology, Egyptian pictorial writing arbitrarily interpreted, Biblical motives, and medieval Christian allegory with all sorts of recondite meanings being assigned to human expressions and actions, to the animals, plants, prescribed colors, and all objects natural and artificial which were their symbolic attributes".

7 Cesare Ripa (1593; 1603; 1971), Stefani (1990, pp. 307-312), Gabriele et al. (2013), Maffei (2009), Cheney (2011a, pp. 567-301), on Vasari's personifications as antecedents of Ripa's figurazioni.

8 See Bartoli (1567), Cecchi (2011), Kliemann (1978), and Bryce (1983), for an insight on this scholar's life.

9 Gioseppe Bettusi da Bassano translated Boccaccio’s Latin edition in 1553, which was published in Venice by F. Lorenzini da Turino.

${ }^{10}$ See Cheney (2012a, pp. 21-66), translated letter of Adriani, original letter in Italian, pp. 67-106.
} 
in the Palazzo Vecchio, in particular, the Sala degli Elementi (Frey, 1923/1930; Muccini, 1990). ${ }^{11}$

Thus Vasari emerged as an artist with a profound humanistic interest. In his early decorative period, Vasari promoted artistic conventions by appropriating all'antica, emblematic, iconographical, and artistic inventions, as seen in the paintings of the Casa Vasari (Cheney, 2006; Jacobs, 1984). Later, in his mature decorative period, Vasari elaborated and expanded upon his earlier artistic conventions in a complex and fanciful visual and intellectual manner. With these artistic patterns in place, he transformed the concept of creating a mythical emblematic painting into a conceit depicting a history painting, as visualized in the Sala degli Elementi. Thus, this particularly holds true in the analysis of his early decorative cycles, namely, his house in Arezzo between 1542 and 1554, a visual prelude to Vasari's later works, the decorative cycles in Florence between 1560 and 1570. In these mature mythological paintings, Vasari repeated and elaborated on his earlier all'antica, emblematic, iconographical, and artistic inventions. In his early decorative cycles, Vasari promoted an artistic convention for future decorative cycles as well as establishing a pattern for the history painting tradition as revealed in the salons of Palazzo Vecchio, in particular, the Apartment of the Elements, where he personified the elements as Saturn, Venus, Vulcan, Apollo, Diana, Pluto, and Mercury.

In his conceit of the personification of Mercury for the Apartment of the Elements, Vasari interwove: (1) the classical literary and visual tradition of The Homeric Hymns in Florentine Renaissance culture; (2) the emblematic and iconographical representation of the planetary influences of the deity; and (3) the alchemical and psychological associations of the mercurial aspects with the activities and personality of his patron, Cosimo 1 de’ Medici.

\section{Impact of the Classical Tradition in Florentine Renaissance Culture}

Among the classical sources that provide insight into Hermes-Mercury's history as a god, a teacher of the arts, and a cosmic planet are The Homeric Hymns (Faulkner, Vergados, \& Schwab, 2016), Ovid's Metamorphoses 1 (668-726), Homer's Iliad and Odyssey, and Hesiod's Theogony or Works and Days. These classical sources permeated Florentine literary culture (Weiss, 1969). Hermes-Mercury's early life is narrated only in The Homeric Hymn to Hermes (Evelyn-White, 1914). He was the son of Zeus-Jupiter and Rhea-Maia. His most important role was that of a divine messenger and an eloquent mediator between the gods and humankind. In this guise, he wears a winged hat (petasus), travel cloak, and sandals (talaria). It is said that he used winged sandals, so he could move faster, hence he was considered the god of wind, motion, and travel; another of his roles was as psychopomp (a guide of souls) (Chevalier \& Gheerbrant, 1994). Thus, Hermes-Mercury was able to travel through the three levels of the cosmos: heaven, the Earth, and the underworld. He also carried a caduceus or herald's wand, decorated with two serpents coiled around the staff with an orb at the top. Other attributes were a rooster, a purse or pouch (satchel), and a tortoise or lyre made of tortoise shell (see Figures 3 and 4) (Chevalier \& Gheerbrant, 1994).

\footnotetext{
11 See Frey (1923-1930), Vol. 1, for the content of five letters dating 1555-1556, No. 220 focusing on the ceiling decoration of the Sala degli Elementi, The Castration of Father Heaven by Saturn, and also Muccini (1990).
} 


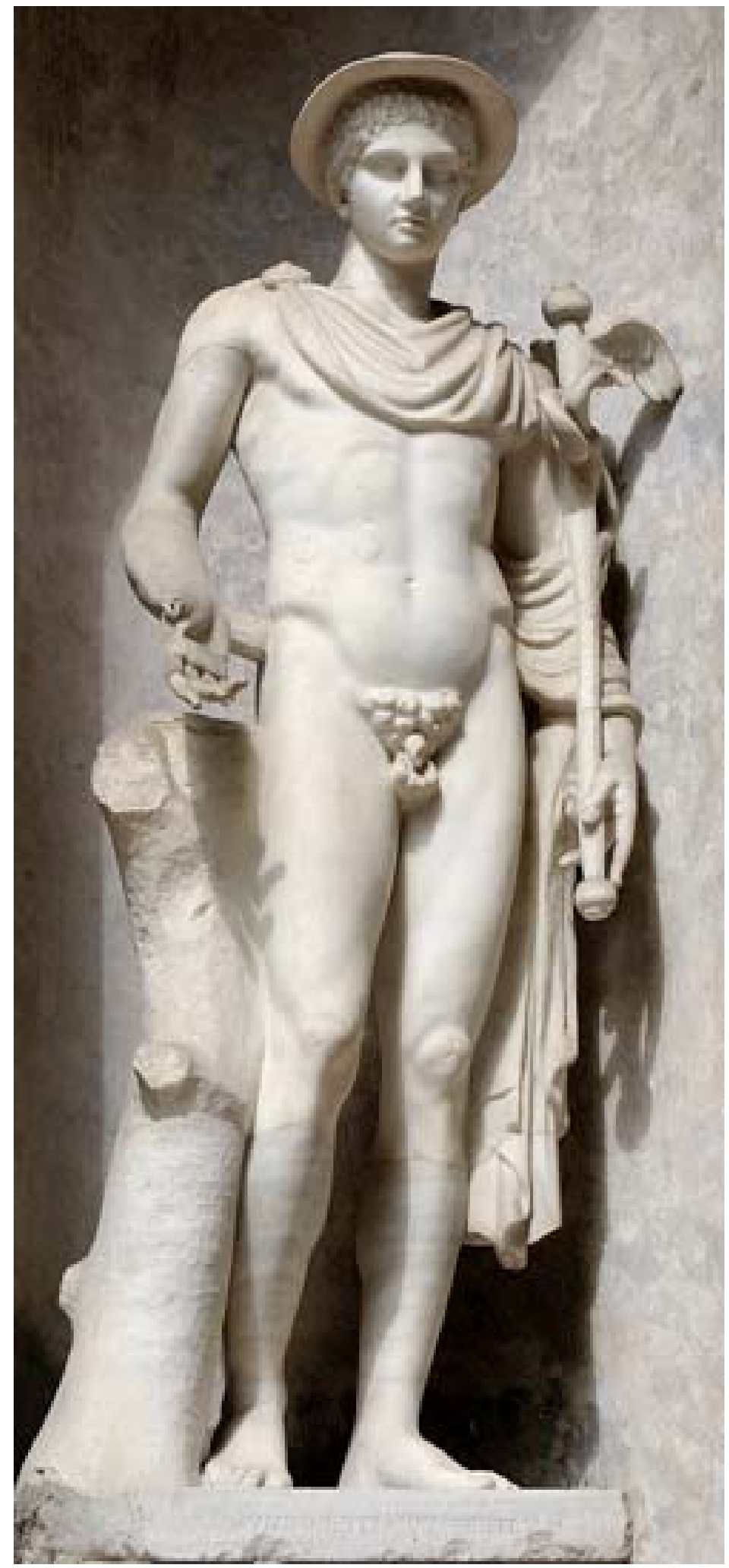

Figure 3. Hermes Ingenui, Roman copy, 2nd century BCE.

After Greek original of 5th century BCE, Vatican Museum, Vatican City. Photo credit: Public domain, Wikipedia.org. 


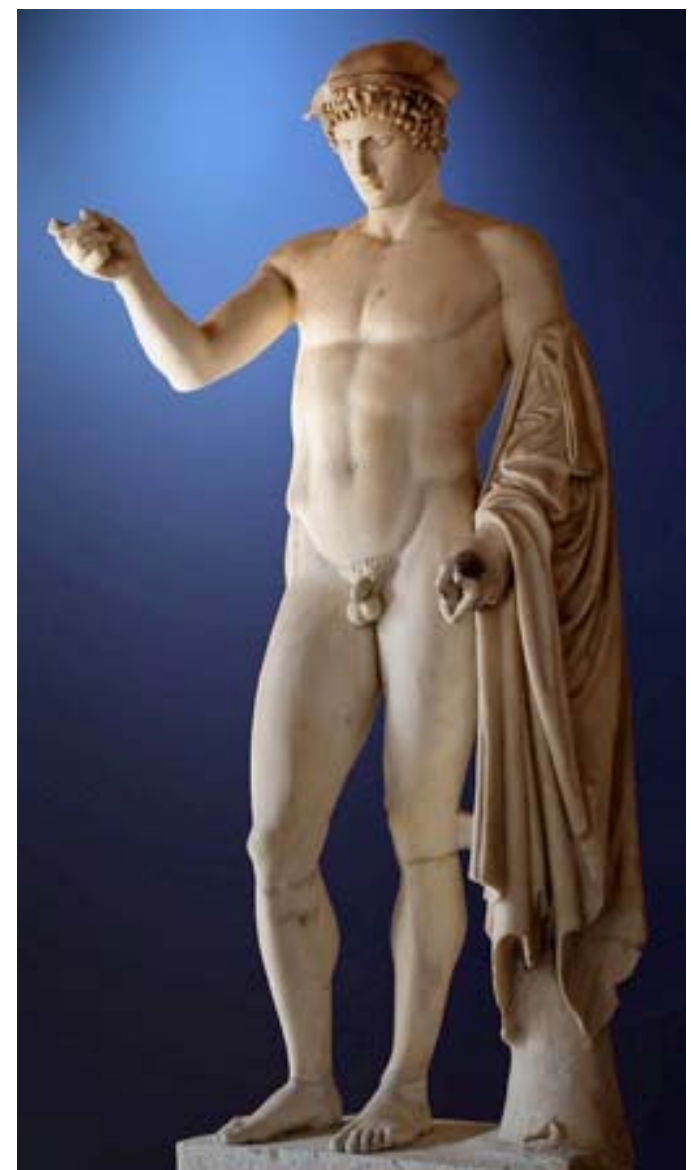

Figure 4. Hermes Orator (Logios Hermes). Roman copy of late 1st century BCE. After Greek original of the 5th century BCE, Altemps, Rome.

Photo credit: Public domain, Wikipedia.org.

In considering these attributes, we find that the cock was a sacred animal usually depicted at Mercury's feet, "a universal solar symbol because its crowing heralds the dawn" (Chevalier \& Gheerbrant, 1994, p. 209). The Homeric Hymn to Hermes accounts as well for Hermes being the god of music and manual skills because he created a lyre. For the box of the instrument, he employed a tortoise shell and made the strings out of cattle intestine. The Hymn further recounts how Apollo became enamored with the sound of the lyre and asked Hermes to grant it to him. Years later, Hermes created another musical instrument, an aulos or flute. Apollo also desired to acquire this instrument and offered Hermes a golden crook in exchange. Agreeing to the trade, Hermes also added a stipulation, requesting from Apollo instruction on the art of divination and magic. These lectures assisted Hermes in foretelling the future with small pebbles. His eloquence in divination attracted the attention of Zeus, the Greek pagan god and king of all the gods on Mount Olympus, who entrusted Hermes with the role of messenger of the gods. The Homeric Hymn to Hermes also emphasizes Hermes-Mercury's pastoral qualities with interests in flocks and fertility (Reid, 1993).

In Roman mythology, unlike Greek mythology, the focus is on Hermes-Mercury as the god of commerce, business contracts and transactions; hence he is often depicted with the attribute of a moneybag or a pouch to reflect this role. The Romans changed Hermes' name to Mercury, alluding to his function as a merchant, since Mercury's name derives from the Latin word "mercari" or "merx", which means, merchant, merchandise, or 
having to do with a commercial venture. The Romans also praised Mercury for his cunning and thievery, while the Greeks honored his manual and oratorical skills. Around 495 BCE, the Romans began worshipping Mercury, dedicating a temple to him near the Circus Maximus. ${ }^{12}$

Renaissance humanists (Brown, 1993) ${ }^{13}$ and artists attempted to explain the multiple facets of the spiritual and artistic conflicts experienced by painters in the process of creation (Roob, 1997). They found their answer in the manuals of mythology and astrology, where the explanation for artistic inspiration and its manifestations were evoked and ruled by planetary gods. For the Renaissance intelligentsia, Mercury, as an astral and mythological deity, epitomized eloquence, agility, and dexterity, and viewed him as a promoter of creativity. He also personified human reasoning, the mental faculty for understanding the external world and its perceptions (Wittkower, 1963). ${ }^{14}$

A favorite motif among Renaissance illustrators was the depiction of the planetary spheres, since they project their influences onto the life and career of individuals born under the auspices and jurisdiction of said planetary sphere (Brown, 2014; Zucker, 1993; Saxl, 1938; M.C., 2008; Ribeiro, 2015). ${ }^{15}$ This type of astral influence was known as the "Children of the Planets", in which each individual was governed by a planetary god, such as Jupiter, Mars, Moon (Diana), Saturn, Sun (Apollo), Venus, and Mercury. For example, Mercury presided over the activities of artists, scholars, merchants, and technicians, as seen in an illustration by Baccio Baldini (earlier attributed to Maso Finiguerra) (Hind, 1938; Phillips, 1955), The Children of Mercury of 1464, now at the British Museum in London (Inv. 1845.0825.475) (see Figure 5). The selection of this subject is an example of a motif derived from this larger astronomical/astrological context generally referred to as to "The Children of the Planets". Although widely known throughout eastern, classical, and medieval cultures, it was particularly in vogue during the Renaissance (Hind, 1938; Warburg, 1969; Saxl, 1919; Panofsky \& Saxl, 1932/1933; Lippmann, 1895).

In the engraving of Baldini's The Children of Mercury, there are two realms: the heavenly and earthly. In the heavenly realm, above the text in the lower part of the print, there is the depiction of a large scroll with the inscription Mercurio, which announces the arrival and transit of the planetary god Mercury. He holds a caduceus while seated on a winged chariot pulled by two large eagles. A large laurel festoon encircles the chariot as a moving majestic cloud. Mercury is dressed in his finest, wearing winged boots and a Florentine-scholar pointed hat with a plume. He embraces an owl, while a rooster rests on a winged arm of the chariot. To define Mercury's planetary governance and astral influence, the engraver designed two wheels with depictions of the zodiac signs of Virgo and Sagittarius. These depictions allude to the positive forces and astral exaltation when Mercury resides in the house of Virgo but also implying the negative forces when Mercury travels through the house of Sagittarius, where Mercury is in its detriment.

\footnotetext{
12 The festival dedicated to him was celebrated on May 15 of each year.

${ }^{13}$ See Brown (1993, p. 290), Fig. 80. The ancient sculptures of Hermes-Mercury suggest the awareness of the astrological powers that this planetary god was thought to have on painters and their art.

${ }^{14}$ See Wittkower (1963), Fig. 19, 103, for an illustration of Hausbuchmeinster's The Children of Mercury, a drawing on parchment of 1480 (Print Room, Wolfegg), representing that those born under Mercury, including sculptors and painters, were industrious, devoted to study, and fond of good living.

${ }_{15}$ See Brown (2014), Zucker (1993, pp. 94-95), Saxl (1938, pp. 72-74), M.C. (2008, pp. 234-235), and Ribeiro (2015, pp. 131-144), for astrological interpretations of the Planets.
} 


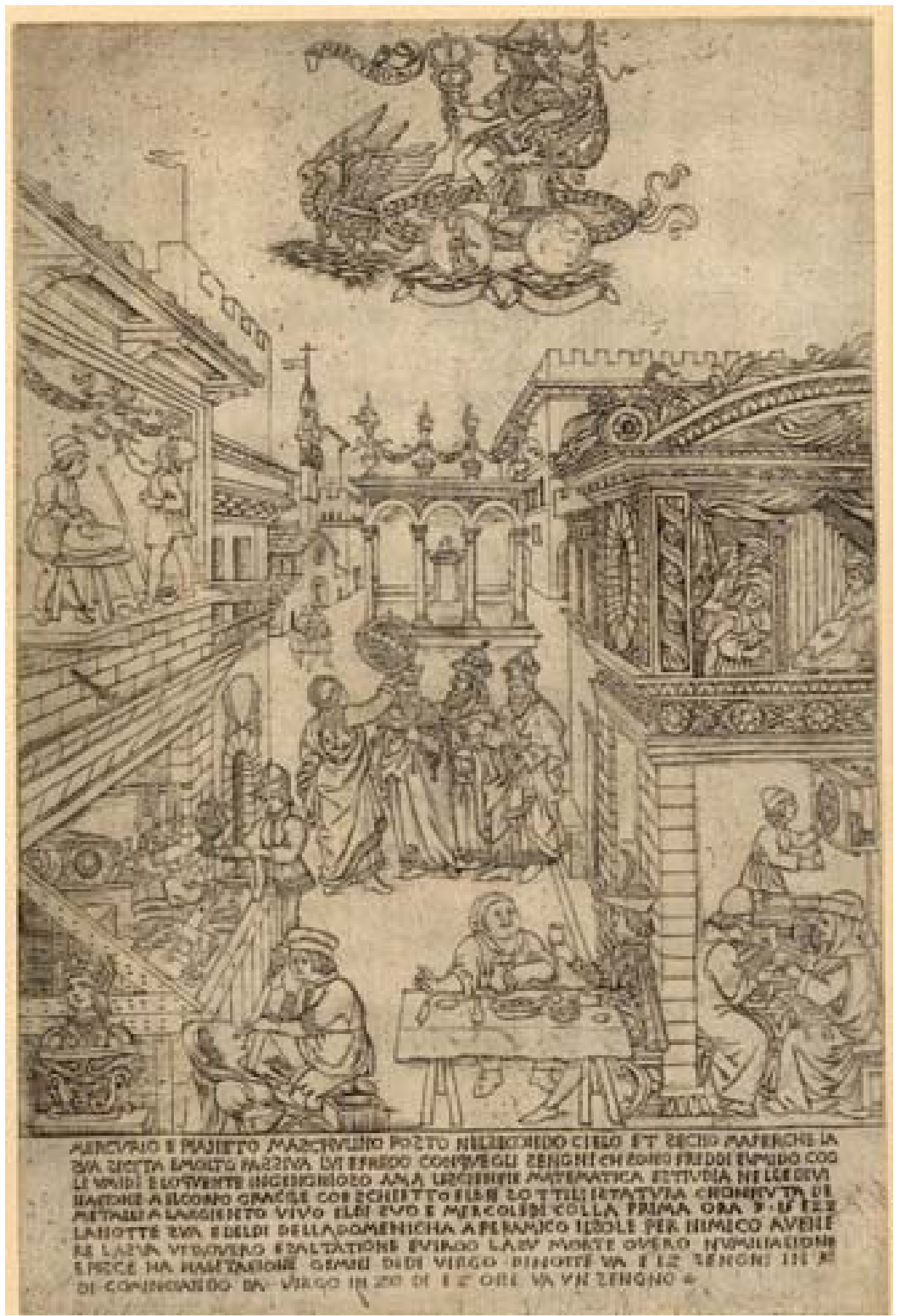

Figure 5. Baccio Baldini, attr. The Planet Mercury, 1464, engraving. British Museum, London (Inv. 1845.0825.475).

Photo credit: British Museum, London. 
According to Jennifer Ehlert, "Of the seven planets represented by Baldini, only Mercury resides over a recognizable area location, Florence” (Ehlert, 2019a, 2019b; Geronimus \& Waldman, 2003, pp. 118-158). In the engraving, Baldini divided the earthly realm into three horizontal levels and three vertical sectors. Horizontally, in the background are architecturally constructions referring to religious (church), public (town hall), and private (palace) buildings. In the middle ground, an open loggia with three entryways contains three standing figures representing ancient astronomers-wearing non-Florentine attire-who are engaged in deep conversation. In front of them, acknowledging their role, the muse of Astronomy raises an astral sphere with an astrolabe and the band of the zodiac. The astronomers' agitated discussion is evident by the presence of this muse who points toward the sky with her spherical attribute, whose astral measurements and motions coincide with the present passing of the planet Mercury. Just above the group is the chariot of Mercury. In the foreground of the print, Baldini represented the practical and professional activities of the "Children of Mercury”, hence revealing Mercury’s astral influence on the terrestrial realm.

In viewing Baldini's engraving in a vertical format further observations can be made. In the center, there is a fanciful architectural depiction of a piazza with a Romanesque church (perhaps the demolished San Pier Scheraggio); next to it is a town hall (Palazzo Vecchio) and across there is private palace (a Medicean palace?). In the center of the piazza, there is an open courtyard similar to the Florentine Loggia della Signoria (Loggia dei Lanzi or the so-called Loggia d'Orcagna). The top of the loggia is decorated with four burning vessels or urns joined together by a garland motif. The vessels are placed directly below the passing chariot of Mercury. The oscillating movement of the burning flames alludes to the volatile power of the planet Mercury. In front of the loggia, as previously noted, three ancient astronomers wearing clothes and hats from foreign lands are discussing the influences of the planets, in particular, those of the planet Mercury. Urania, the muse of Astronomy, joins them in the discussion by pointing to the sky and bringing an astrolabe sphere with layout concordances that match the present astral trajectory of Mercury above them (Shackford, 1923). ${ }^{16}$

The astronomers' placement in the middle of the piazza forms the separation between the vertical left and right of the print as well as the two distinct types of building architecture. In addition, their presence and astronomical knowledge alludes to the astral bond that unifies the purpose of the activities of the "Children of Mercury”. On the left side, the architecture represents public edifices where laborers are working. On the top level of one of the edifices, a painter and his assistant are preparing an exterior wall for a fresco decoration. All types of painting tools and materials are visible on the edge of the platform where they stand to perform their creation and tasks. The area below them is the ground floor of the building, showing an open artist's workshop displaying ceramics, leather belts, and other handmade artifacts. A customer has approached the shop to purchase a ceramic vase. In a corner of the shop, an engraver is designing a figure on a tablet. In front of him are numerous tools for woodcarving and metal engraving employed by artists. Around the corner from the shop, a large marble bust of winged Mercury is displayed on a pedestal, while next to it another marble sculpture of a woman is being carved out. This artist is holding a hammer and a chisel and carefully renders the form. A display of boxes and chisels surround the sculptor, his tools contrasting with the tools employed by the engravers in the workshop. An interesting vignette that refers to an artistic paragone between two-dimensional versus three-dimensional representation constructs—relief (engraving) and versus freestanding (marble

\footnotetext{
${ }^{16}$ In “Chosen Ones: Mercury and the Concept of Gnosis in Baccio Baldini’s Children of Mercury”, Ehlert pointed out that these three figures could be the personification of the Magi as prophetic images similar to Mercury as well as exotic figures depicting the Medicean interest in Eastern cultures. Her observations are further elaborated in Shackford (1923, pp. 377-387).
} 
carving)—but both relying on artistic invention.

On the right side of Baldini's print, the edifices represent private dwellings, a palace, or an academy; hence the architectural construction is fancier in comparison to the public architecture seen across the street, on the left side of the print. The top floor shows, through a window, a group of musician listening to one of them playing the organ, while an assistant works the bellows for the pipes of the organ. On the floor below in the same building, an open door to a bookshop shows a group of scholars surrounded by books and consulting them. In the background, a young assistant winds up a clock. Another charming vignette where scholars who have lost the track of time while engaged in their intellectual pursuit are contrasted with the practical task of a young clock-winder busy keeping tab of time.

Outside the building and next to the sculptor, two people are engaged in easy living: They are conversing while eating and drinking. Their attire is similar to the architectural construction; one of them is dressed in domestic clothes while the other wears a princely outfit. In summary, in the realm of Earth, the "Children of Mercury"-consisting of astronomers, scholars, and merchants-are engaged in the art of conversation and eloquence while painters, engravers, ceramicists, and sculptors are striving to create artistic forms. Hence, the "Children of Mercury" are comprised of both thinkers and doers (Panofsky \& Saxl, 1923/1933; Wittkower, 1963). ${ }^{17}$

In the visual traditions of Italian Renaissance, in particular, in the planetary depiction of the pagan gods, Mercury appears holding a moneybag in one hand and two entwined snakes in the other hand. In his astral, aureole are the usual zodiac signs of Gemini and Virgo — his planetary constellations—as seen in Cristoforo de Predis's Mercury in De Sphaera coelestis et planetarum descriptio, a Milanese manuscript of the 15th century located in the Biblioteca Estense of Modena (Ms. lat. 209, fol. 11 and 11r) (Pedersen, 1985; Thorndike, 1949). ${ }^{18}$ This beautifully illustrated manuscript was probably commissioned by Francesco Sforza, Duke of Milan, and his wife Bianca Maria Visconti around 1455 for the dowry of Anna Sforza, wife of Alfonso I d'Este (see Figures 6 and 7) (Trottein, 1993).

\footnotetext{
17 During the Renaissance there were many versions of the Children's Planets, e.g., Master of the Housebook's Children of Mercury of 1480, a planetary series in the Housebook located in the Print Room of the Wolfegg Castle in Germany. It is not the intention of this essay to discuss them.

${ }^{18}$ In the 13th century, Johannes de Sacrobosco (John Holywood) wrote a didactic and scientific treatise on the history of astronomy, which was called De Sphaera mundi (On the Sphere of the World). This codex, based on Islamic and Ptolemaic astronomical concepts, became a very popular university text in astronomy from the 13th century till the 16th century, including at the Sorbonne in Paris where Sacrobosco taught for several years. During the Renaissance many copies were made, including the 1472 edition for the Sforza/d'Este family, known as the De Sphaera estense. For an English translation of the Sacrobosco's De Sphaera mundi, in particular, the chapter associated with Mercury: "THE HEAVENS: Around the elementary region revolves with continuous circular motion the ethereal, which is lucid and immune from all variation in its immutable essence. And the philosophers call it 'Fifth Essence'. Of which there are nine spheres, as we have just said: namely, of the moon, Mercury, Venus, the sun, Mars, Jupiter, Saturn, the fixed stars, and the last heaven. Each of these spheres encloses its inferior spherically”.
} 


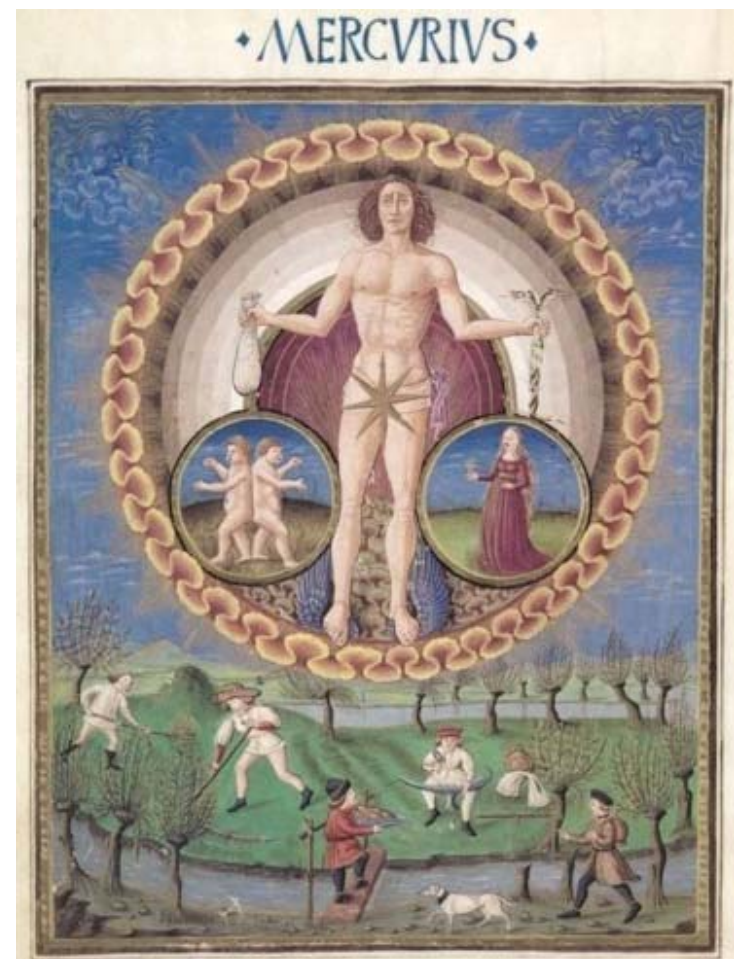

Figure 6. Cristoforo De Predis, Mercury, 1470, from De Sphaera. Biblioteca Estense, Modena (Codex. Ms. Lat. 209). Photo credit: Public domain, Wikipedia.org.

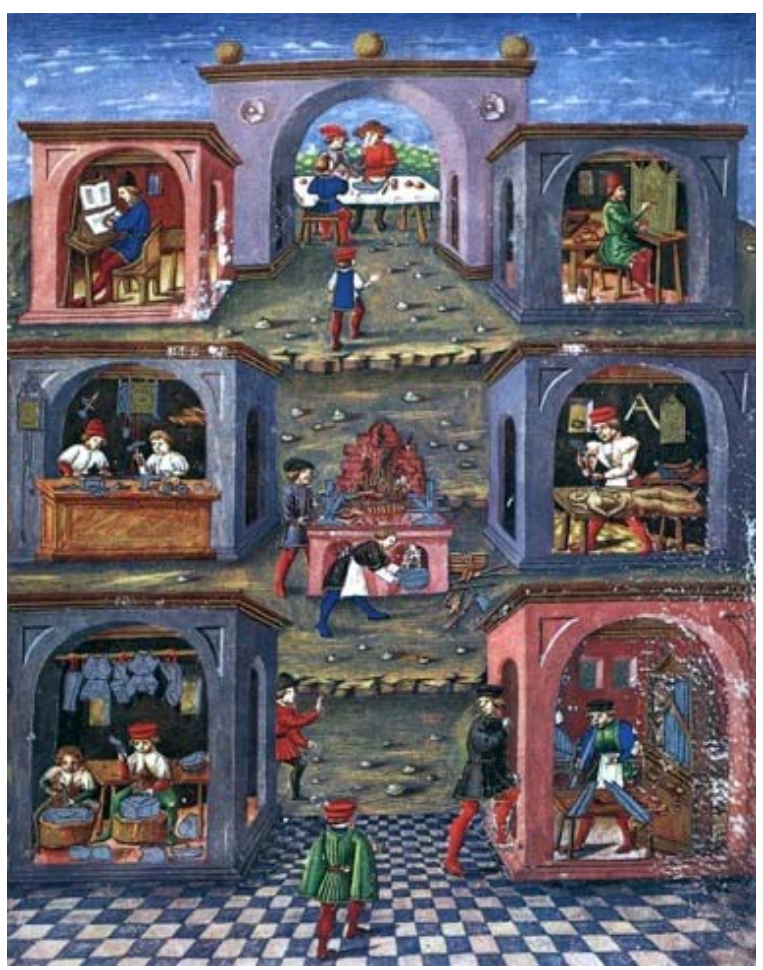

Figure 7. Cristoforo De Predis, Mercury, 1470, from De Sphaera. Biblioteca Estense, Modena (Codex. Ms. Lat. 209, fol. 11r). Photo credit: Public domain, Wikipedia.org. 
In the page depicting the planetary god, Mercury, below the astral aureole, de Predis represented a terrestrial landscape where the "Children of Mercury"-those individuals born under the planetary influence of Mercury—are cultivating the soil while others are traveling about (Trottein, 1993). ${ }^{19}$ In the adjacent folio, de Predis elaborated on the depiction of the various activities conducted by the "Children of Mercury". At the top of the folio, a celestial background populated with clouds contrast with a terrestrial ground divided in three layers. On each layer, there are small vignettes constructed as early Renaissance workshops of arts and trades with open and closed entrances. The central vignette, constructed as a loggia with a large round arch, is decorated with three large spheres at the top. Inside the workshop are individuals, born under this planet, actively engaged in writing, painting, carving, sculpting, making musical instruments, clocks, and armors, as well as enjoy drinking and eating, while others are travelling from one shop to another, conversing or purchasing some of the original artifacts. In this format, De Predis seemed to refer to the Florentine guilds (Staley, 1906). In order to unify the laid-out space of the workshops in the three different levels with the corresponding activities of the "Children of Mercury" performed inside their respective studios, small white pebbles simulating clouds are dispersed throughout the terrestrial layers, paralleling the scattered clouds seen in the blue sky.

The astral connection of Mercury with his associations seen in the imagery of Baldini and de Predis are considered as an almanac or a calendar of human activities. These representations contrast with another type of light-hearted visualization, playing cards or trionfi (triumphs) (Weisbach, 1919/2010). ${ }^{20}$ This playful representation became known as tarocchi or Tarot cards, a popular entertainment in the 15th century. These cards contained images with allegorical meanings or depicted personifications of abstract conceits, which at some unknown time in history became associated with astral prophecy or divination (Place, 2005). Mantegna's Mercury, for example, a Tarot card engraved between 1465 and 1470, now at the British Museum in London (see Figure 8), depicted the personification of the planet Mercury with his traditional attributes. Here, Mercury is engaged playing the aulos while holding the caduceus, both traditionally considered healing instruments. At his feet, Argus's head and a cock are added to Mercury's attributes as well as referring to his tasks, as messenger of the gods by slaying Argus to fulfill Jupiter's wish in freeing his pregnant lover Io from inside the stomach of a cow, and partaking of the rising sun as when the rooster crows at dawn.

\footnotetext{
19 Although the focus here is on the "Children of Venus", the same cultural, philosophical and astrological literary, and visual sources can be applied to the "Children of Mercury".

${ }^{20}$ Weisbach (1919/2010), a careful study about the meaning and application of the term in Renaissance culture.
} 


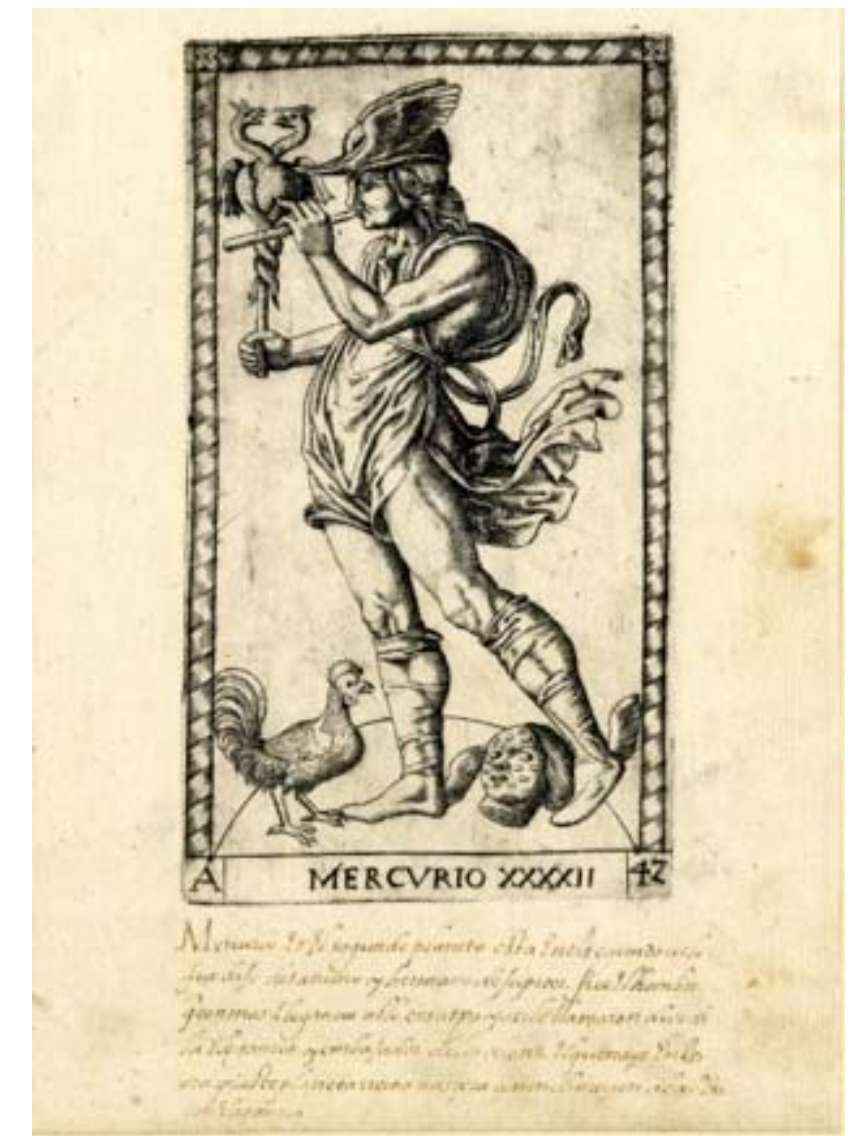

Figure 8. Andrea Mantegna, Mercury, 1490, engraving, Tarot Card.

British Museum, London (1895.0517.142-AN83764001).

Photo credit: British Museum, London.

During the Renaissance, the fascination with ancient mythology and the mythical behavior of the pagan gods was further visualized in paintings, for example, Dosso Dossi's Jupiter, Mercury and Virtue (Ceres, Iris or Flora) of 1524, at the Wawel Royal Castle in Krakow (see Figure 9), where Mercury is represented with other pagan deities (Fiorenza, 2008). ${ }^{21}$ In this painting, Mercury is under the spell of a godly activity; his planetary influence is switched from his contact with terrestrial beings to interactions with celestial divinities. In the painting, Mercury, with his index finger, silences his companion as not to interrupt Jupiter's creative process in painting butterflies (Humfrey \& Lucco, 1998). ${ }^{22}$ In part, this imagery alludes to Mercury’s advice to the gods of the essential necessity of stillness or suppression of speech or noise when seeking wisdom or during the process of creation.

\footnotetext{
${ }^{21}$ See Fiorenza (2008, pp. 21-48), esp. 32, for an attribution to the personification of Flora instead of Ceres, Iris, or Virtue.

22 See Humfrey and Lucco (1998, pp. 170-171), for an attribution of Ceres or Iris as Virtue.
} 


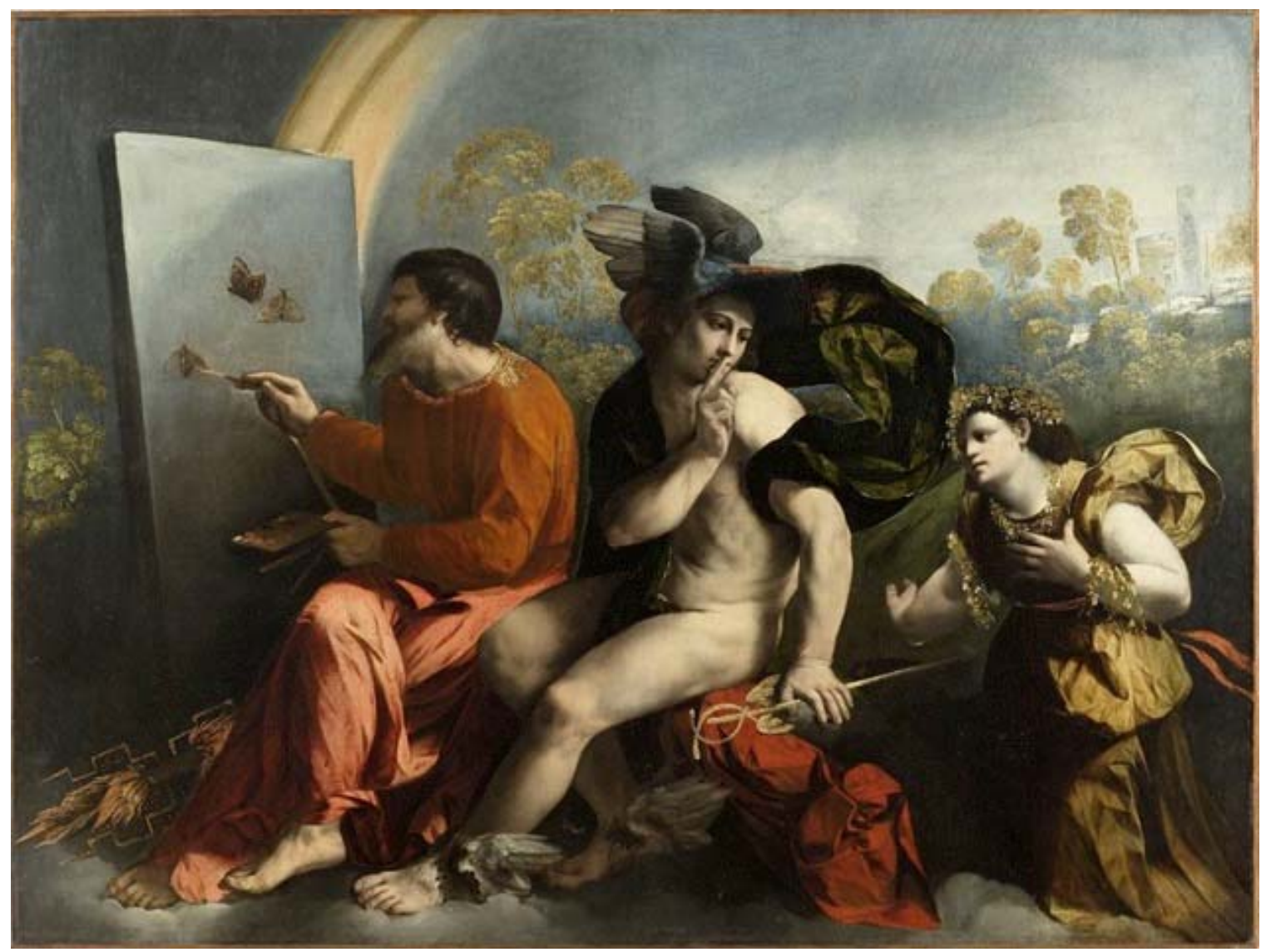

Figure 9. Dosso Dossi, Jupiter, Mercury, and Flora, 1524.

Wawel Royal Castle, Krakow.

Photo credit: Public doman, Commons.wikimedia.org.

Mantegna's solo depiction of Mercury on a tarot card contrasts with Dossi's beautiful painting, where Mercury is gathering with the gods: a juxtaposition of the small and private usage of a playing card to the public visualization of a decorative panel painting. Dossi invented a thematic subject where Mercury observes an artistic creation in a celestial realm, while Mantegna composed a figure of Mercury with attributes but isolated from the astral implications to those born under his planetary signs. The signification of his imagery and attributes depend on the interpretation of a player or a viewer and not on the god's astral benefits. Mantegna's imagery of Mercury is also different from the almanac representations of Baldini and de Predis, where the focus is on the planetary influence of the Mercury on those individuals born under his sign. Vasari too composed several images of Mercury in drawings and paintings, focusing on his solo image as personifications of the God of Commerce, Eloquence, and Wisdom with astral powers.

\section{Vasari’s Mercury and Cosimo I de’ Medici}

Before portraying the Mercury (Florentine Mercury) in the Sala degli Elementi of Palazzo Vecchio, Vasari depicted an image of Mercury with attributes of the zodiac on the ceiling of the Chamber of Fortune in his home at Arezzo in 1548 (see Figure 10). The Aretine Mercury is a beardless young man wearing a small round winged hat and holding a winged caduceus while playing the flute. With his musical instrument, Mercury is lulling to sleep Argus, the hundred-eye monster. In a reclining pose, Mercury rests on Argus's large head. 
Framing this scene are his zodiac sings: Virgo, a suspended figure on the left, and Gemini, two embracing cupids on the right (Ficino, 1489/1576/1959; Moore, 1990; Kaske \& Clarke, 1489/2002; Allen, 2002; Voss, 2006). In the coffered ceiling of the chamber, Mercury is placed along with the other six planetary gods-Apollo, Diana, Jupiter, Mars, Venus, and Saturn—a pantheon of the pagan gods, protecting Vasari's household and guiding and imbuing his artistic and intellectual endeavors with prosperity (Cheney, 2000; 2003).

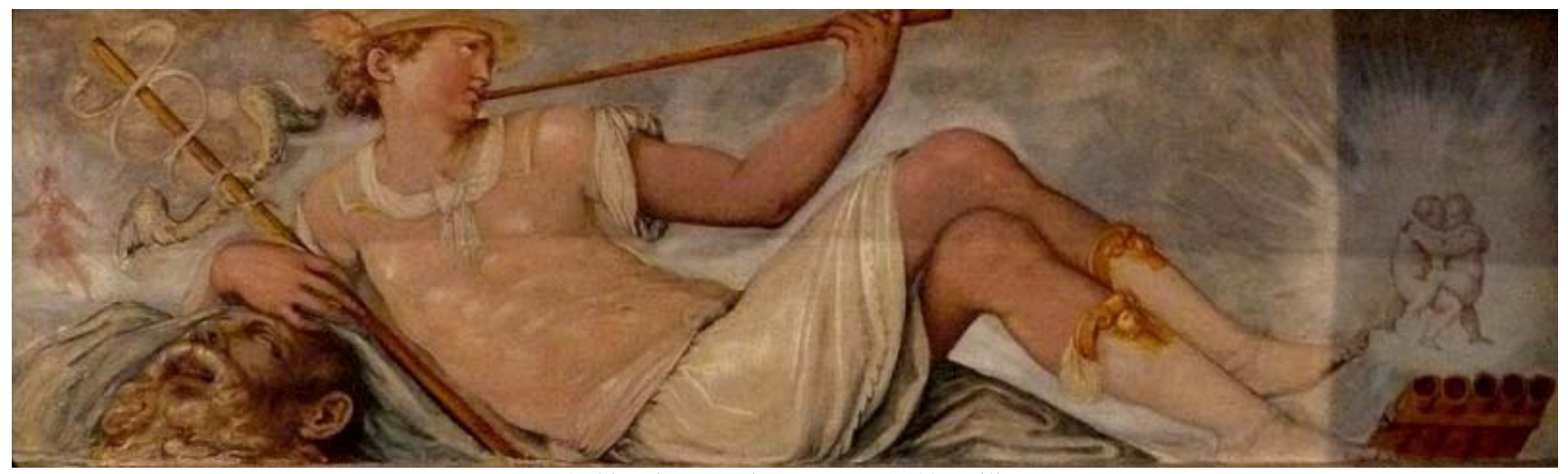

Figure 10. Giorgio Vasari, Mercury, 1548, ceiling.

Chamber of Fortune, Casa Vasari, Arezzo.

Photo credit: author.

Fascinated with this image, Vasari composed another image of Mercury but in a drawing in pen and brown ink, now located at the Pierpont Morgan Library in New York (1984.62.1), a gift of the János Scholz Collection (see Figure 11). According to Florian Härb, this drawing of 1553 is a study for fresco decorations in Bindo Altoviti's villa in Rome (Härb, 2015). These frescoes originally represented the personifications of the seasons and nine deities but were destroyed around 1864. Fortunately, engravings from Tommaso Piroli published in 1807 assisted in reconstructing the decorative cycle. However, further damage occurred to the villa before its demolition in 1888. Other surviving decorative cycles (12 months, two river gods, and a personification of Ceres) were transferred to Palazzo Venezia in Rome (Chong, 2003). 


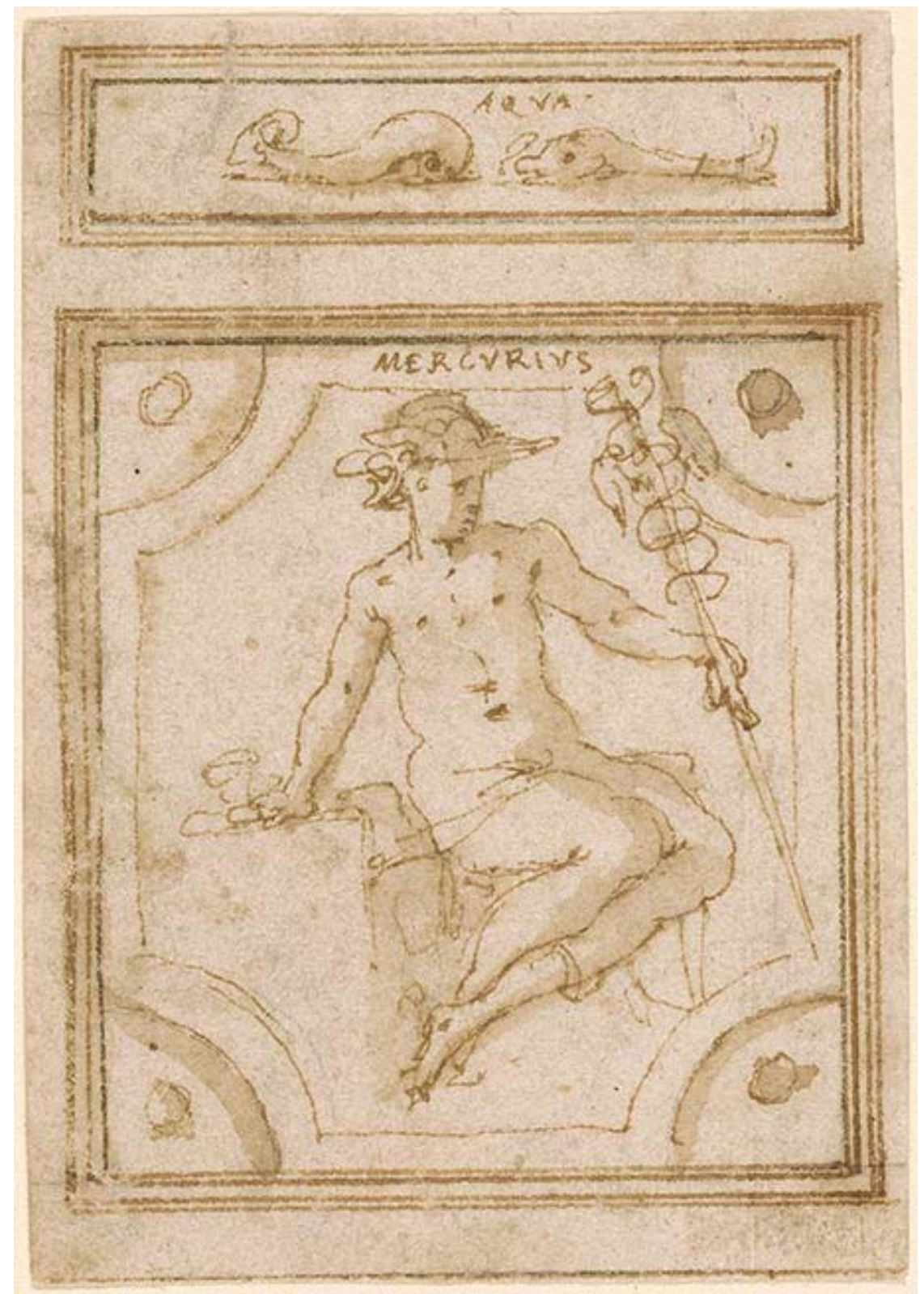

Figure 11. Giorgio Vasari, Mercury, 1553, drawing.

Pierpont Morgan Library, New York (1984.62.1), Gift of János Scholz.

Photo credit: Pierpont Morgan Library, New York.

In this drawing of Mercury, Vasari designed a frieze above the imagery of the pagan god containing two dolphins and an inscription, "Aqua” ("Water"). A strange astrological connection, since Mercury rules the zodiac signs of Gemini, mutable air, and Virgo, mutable earth. Below the Italian inscription, the image of Mercury is drawn as a nude male seated on a throne, holding a caduceus in one hand and resting the other hand on a pouch. His head is crowned with a winged shepherd hat, recalling the Florentine shepherd hat of Donatello's David of 1440 at the Museo Nazionale del Bargello in Florence. In depicting Mercury in a seated pose with his legs partially crossed, Vasari appropriated a composition from another Florentine sculptor, Michelangelo's Lorenzo de' Medici, Duke of Urbino of 1525, in the New Sacristy of San Lorenzo in Florence. 
But Vasari's most inventive and complex portrayal of Mercury is visualized in the Sala degli Elementi (see Figure 12). In a tour-de-force design in the fresco technique, the simulated fine arts of architecture, sculpture, and painting merge into a spatial unity like the threads in a woven tapestry. Along the wall with windows there are three simulated triumphal arches, each encasing niches containing arched glass windows (Draper, 1973; Allegri \& Cecchi, 1980). ${ }^{23}$ The mural sides of each niche, as well as the friezes above the arches, are filled with grotesque ornamentations (Allegri \& Cecchi, 1980, Cecchi, 1977; Passignat, 2013). ${ }^{24}$ Projecting from the posts of the triumphal arches are two projecting altars in grisaille with garland decorations, suspended from the ceiling by putti. Inside these simulated altars are two large standing figures as simulated sculptures representing Hermes-Mercury and Hades-Pluto with their respective attributes (del Vita, 1938; Allegri \& Cecchi, 1980). In their corresponding areas, the gods turn to face each other. In the center of the lintel frame above their heads are masks of voracious owls. The pedestal of each statue is decorated further with classical motifs and large medallion with vignettes, today illegible.

The imagery of the Florentine Mercury is a unique Vasarian conceit (Vasari, 1568; Passignat, 2019). ${ }^{25}$ Unlike the reclining Aretine Mercury in a coffered ceiling, the Florentine Mercury heroically stands in a simulated altar. But both images symbolically connected with the overall narrative in their respective chambers, dealing with celestial and terrestrial cosmic interactions (compare Figures 10 and 12) (Cheney, 2018).

In I Ragionamenti, First Ragionamento about the Sala degli Elementi, Vasari began to unveil his imagery and symbolism (Draper, 1973; Tinagli, 2001; van Veen, 2014; Passignat, 2007, 2009a, 2014; Giani, 2011). ${ }^{26}$ In the dialogue between the Prince and himself, Vasari first explained the identification of each pagan god and then the symbolism for its placement and its relation to Cosimo I de’ Medici.

I [the Prince] see him [Mercury] between the two windows holding a caduceus, with a winged hat and winged feet.

([Mercurio]....Io [Prince] lo veggo fra due finestre col caduco in mano, col cappello alato, e i piedi).

\footnotetext{
${ }^{23}$ From Vasari's description of the chamber, originally these windows contain stained glass with personifications of Fortune, Envy, Astraea, Unity, and Concord with corresponding Latin inscriptions. See Vasari-Milanesi, I Ragionamenti, VIII, 34; Draper (1973); and Allegri and Cecchi (1980).

${ }^{24}$ Probably executed by Marco da Faenza under Vasari’s supervision. See Allegri and Cecchi (1980), Cecchi (1977), Passignat (2013), and Emilie "Des frises, des emblems, des festoons, des grotesques: Giorgio Vasari et le cycle decorative du Palazzo Vecchio à Florence", in Questions d'ornements: XVe-XVIIIe siècles, R. Dekoninck et al. (Turnhout: Brepols Publisher), pp. 252-265. A payment record dated January 14, 1557/1558 lists Arrigo Fiammingo (Hendrick van der Broech, 1530-1597) completing four stained-glass windows in the Sala degli Elementi (ASF. F.M. 3.c 11v), see Allegri and Cecchi (1980).

${ }^{25}$ Cristofano Gherardi assisted in the execution of Vasari’s conceit. See Vasari (1568), ann. and ed. Gaetano Milanesi 9 vols (Florence: G. C. Sansoni, 1878-1885, reissued in 1970), VI, pp. 229, 232-232, 237. Hereafter cited as Vasari-Milanesi. See also Emilie Passignat (2019).

${ }^{26}$ See Vasari-Milanesi, VIII, I Ragionamenti. For an English translation, Draper (1973), Tinagli (2001, pp. 63-76), van Veen (2014, pp. 163-177, Passignat (2007, pp. 115-128), Passignat (2009a, pp. 67-79), Passignat (2014, pp. 151-163), for current bibliography on this topic, and Giani (2011).
} 


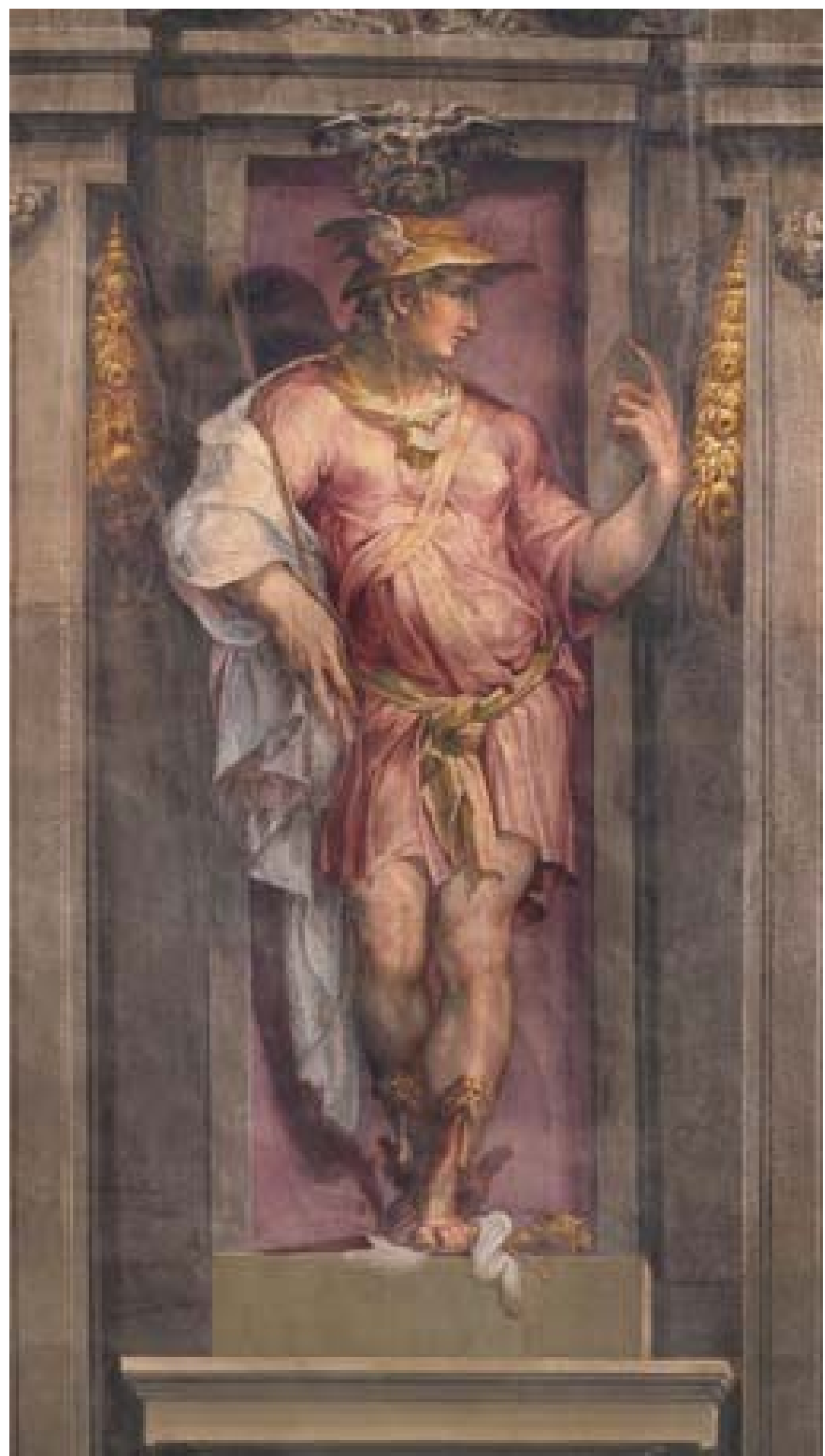

Figure 12. Giorgio Vasari and Cristofano Gherardi, Mercury, 1555-1556. Window wall. Sala degli Elementi, Palazzo Vecchio, Florence. Photo credit: HIP, Art Resource, NY. 
In the painting, stepping out of a niche decorated at top with a large mask of a voracious owl, Mercury stands on a large pedestal. His body is paradoxically composed of two types of male figures: a sensuous Apollonian figure and a Herculean muscular body. Apollonian Mercury is designed in a contrapposto stance, clothed with a short pink tunic similar to an ancient Roman tunic. ${ }^{27}$ The treatment of the drapery both conceals and reveals the body-a classical wet-drapery motif. A golden strap across his chest holds the cloak over his shoulder. Two golden scarves with large knots embellish his tunic. One scarf decorates his neckline, framing his Apollonian head in profile, and the other, whose prominent knot functions as a codpiece, accentuates his hip. The short tunic reveals Mercury’s muscular Herculean legs (Wallace, 1997; Barocchi \& Ristoi, 1965/1983). ${ }^{28}$ Winged boots with open toes and a winged hat are flying attributes of Mercury. His hat is similar to a Tuscan shepherd's hat. Vasari repeated this motif earlier in a drawing of Mercury (compare Figures 12 and 11). The Florentine Mercury is holding a herald's wand or a shepherd's stick with his right hand, and pointing upwards with a tapered index finger of his left hand. His exaggerated pointing gesture is a Mannerist conceit alluding to the god's rhetorical eloquence. In Vasari's painting, the caduceus, Apollo's gift in exchange for Hermes's aulos, is depicted at the feet of Mercury. This unusual caduceus has a snake surrounding a goat's head, a reference to the god's Etruscan origins (Combet-Farnoux, 1980). ${ }^{29}$

Perhaps this conceit—snake and goat's head—also refers to the Etruscan Chimera of Arezzo of 400 BCE (now in the Museo Archeologico Nazionale in Florence), discovered near Porta San Lorentino in Arezzo on November 15, 1553 (Pallottino, 1977; Hillard, 2013). Vasari ensured that Cosimo I de' Medici, an avid collector of Etruscan artifacts, would receive this precious archeological discovery (Gáldy, 2009; Cheney, 2016). Underneath Mercury's winged sandal-boot, a white scarf, whose meaning is yet unclear, covers part of this rare caduceus.

When Cosimo I de' Medici assumed control and governance of Florence in 1537, he started developing a passionate interest in collecting Etruscan sculpture and artifacts as part of Florentine history and patrimony (Hillard, 2013). Aware of this personal curiosity, friends and famous dignitaries contributed to his collection. In 1550, for example, the duke received a remarkable gift from Pope Julius III: A statue of Mercury, much battered and then restored, originally located in a covered gallery located just behind the statue court of Belvedere (Haskell \& Penny, 1981). Additionally, Vasari's classical composition and expression of the painted Mercury in the Sala degli Elementi indicate his close familiarity with the newly acquired Medicean Mercury and the Roman Apollo Belvedere. With the exception of Vasari’s stylistic appropriation of the Mercury statue, there was little interest in Florence in the Roman image, despite its replica in bronze commissioned by Cosimo I de’ Medici for his favorite courtier, Antonio Montalvo. This replica may be the statue at the Pitti Palace or the one at the National Gallery of Art in Washington, D.C. (see Figure 13) (Haskell \& Penny, 1981). ${ }^{30}$

\footnotetext{
${ }^{27}$ For an Apollonian image known to Vasari, see Apollo Belvedere after Leochares, 120 CE, Vatican Museums, Vatican City, see https://en.wikipedia.org/wiki/Apollo_Belvedere (accessed August 15, 2019).

${ }_{28}$ Vasari was also recalling Michelangelo’s sculpture. See Wallace (1997), and esp. 1251, citing Sebastiano del Piombo’s praise of Michelangelo's knees: “The knees of that figure are worth all of Rome”, in Barocchi and Ristoi, 1965/1983, 2, p. 314.

${ }^{29}$ See Combet-Farnoux (1980, pp. 171-217), for a discussion on the Etruscan god Turms as equivalent to the god Mercury and perhaps the Roman Mercury, being Etruscan in origin.

${ }^{30}$ Vasari's contemporary sources are, of course, Donatello's David of the 1430s, sometimes referred to as the Mercurial-David; Michelangelo's David of 1504; and Cellini’s Mercury of 1558, placed at the base of the Perseus statue.
} 


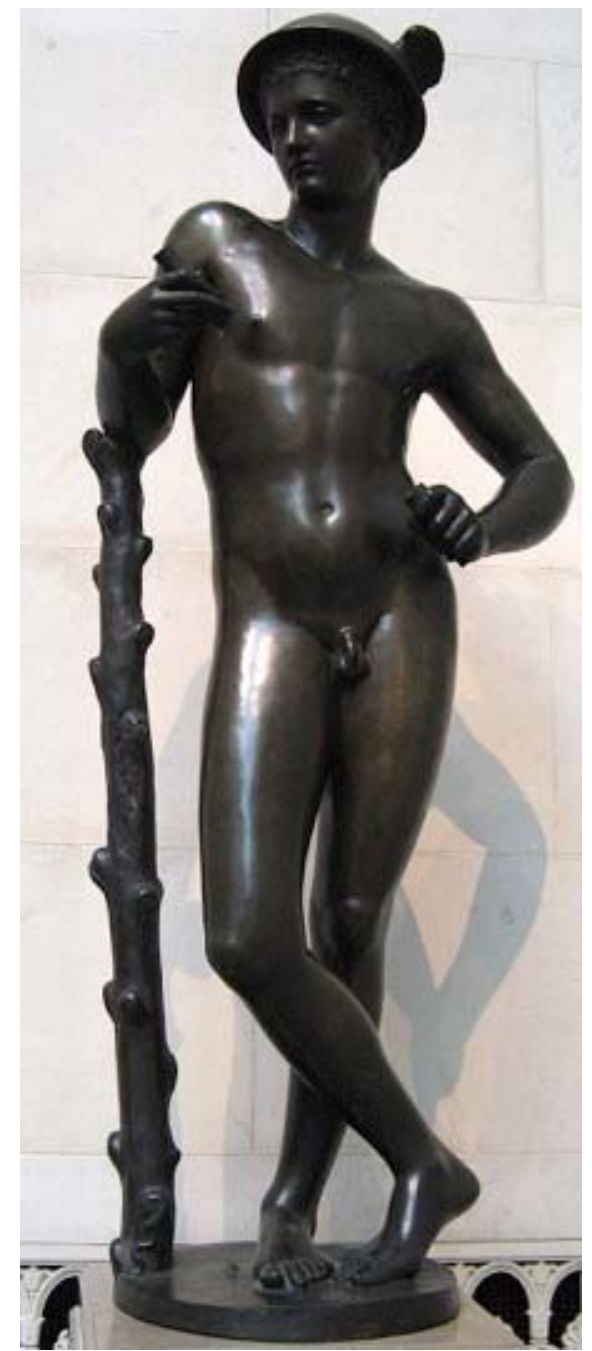

Figure 13. Anonymous, Mercury, 16th century copy. National Gallery of Art, Washington, D.C.

Photo: author.

In I Ragionamenti, First Ragionamento, Vasari continued to explain Mercury's symbolism to the Prince by writing:

Mercury could not be absent here for another reason also, my lord. As the master of eloquence and the messenger of the celestial gods in all matters, he too relates to our Duke, who is most mercurial and skillful in dealing with eloquent men. How much he is like Mercury in his ability to distinguish hidden truths and sophistries, and in the great delight he takes in understanding mining and alchemical experiments, [as well as] the secrets of nature for powerful remedies against illness that inflict the human body. All these elements are attributes of Mercury

(Questo [Mercurio], Signore, ci mancava, perché essendo egli sopra l'eloquenza, e in tutto messaggiere degli Dei Celesti, non meno lo esercita il nostro Duca, il quale è Mercurialissimo sì per propria virtù nel negoziare, sì per gli uomini eloquenti, e sì per la cognizione che ha delle miniere e dell'Alchimia e de'segreti di natura, e rimedi potentissimi contro le malattie, che infettano i corpi umani, tutte cose attribuite a Mercurio).

The most intriguing aspect of Mercury, however, is his beckoning gesture conveying a message to the adjacent companion, Hades-Pluto, the God of the Underworld. Vasari's commentary on Pluto assists in understanding this action. In I Ragionamenti, the Prince inquired: "Why did you include Pluto with the dog 
Cerberus, putting his arms on a two-pronged pitchfork?” (Ma perché ci fate voi Plutone col Cane Cerbero, il quale pose le braccia in sul bidente?) In the dialogue, Vasari as Giorgio replied to the Prince:

Mines are located underground where Pluto is prince, and likewise the riches and treasures, which are necessary to mercurial individuals. Although I had the knowledge to make these rooms, even others are more beautiful, the task could not have been undertaken without the money, the commodities and the riches of Duke Cosimo, prince of that wealth.

(Le miniere sono sotto la terra, delle quali Plutone è principe e così le ricchezze e i tesori, il quale Mercuriali non possono far senza esse, come sarebbe intervenuto a me, che se bene io sapeva fare queste stanze e ancora delle più belle, non si potevano fare senza i denari e le comodità e le ricchezze del duca Cosimo principle di quelle).

Vasari's Herculean Pluto is accompanied by the vicious three-headed dog, Cerberus, who guards the gates of Hades (see Figure 14) (Hansen, 2005; Vernant, 2001). ${ }^{31}$ In his niche, the semi-nude Pluto turns to attend to Mercury's gesture. Despite the criticism of the muscular handling of Baccio Bandinelli's Hercules and Caucus of 1534 in Piazza Signoria, Vasari's treatment of the body and facial expression is very similar (Kieft, 1994). ${ }^{32}$ His yellow cloak is tied up in front of his voluminous chest, while part of cloak falls behind his body and an edge is pulled across his genitals, which are covered by a scarf; both items function as a codpiece for the god. Pluto firmly holds the pitchfork where his left arm rests. Two heads of Cerberus growl while the third watches. Unlike the elegant sandal-boots of Mercury, Pluto's footwear is that of a working peasant. Curiously, another Vasarian artistic quotation is appropriated from Bandinelli's statue: Hercules's turning head and the treatment of his curly hair. In the painting, Pluto's curly beard is of similar design to his unkempt hairdo but a red sash can be seen through the curls on his head, holding together his hair and adding whimsicality to this potent god of the underworld. Vasari depicted a Hades-Pluto in the Roman tradition where Pluto is confounded with Plutus, god of abundance, riches, wealth, and minerals, for these stones and metals are hidden deep in the earth, in the underworld. Pluto was also venerated as the god of fertility with a symbol of a "horn of plenty" (Athanassakis, 1983/2004, p. 56; Hansen, 2005, p. 183; Williams, 1994, p. 90) 33 $^{33}$

In the Renaissance tradition, the depiction of Pluto, although rare, was fused with Hercules's labor in the underworld. Perhaps the relation reflected the cosmic association between Hercules and Mercury noted in ancient astrological texts. At the same time, the well-known connection between the two gods, Mercury and Pluto, refers to the request of Pluto's sister Demeter to Zeus, who commands Hermes to travel to the underworld and persuade Hades-Pluto to allow his bride and niece, Persephone or Proserpine, to return to Earth to visit her mother Demeter (Martin, 2003). Because of their contact with the underworld, both gods were viewed as promoters of sleep; for example, Hermes-Mercury as inducer of meditative sleep, and Hades-Pluto as promoter of forgetful sleep.

\footnotetext{
${ }^{31}$ See Hansen (2005, pp. 180-182) and Jean-Pierre Vernant (2001), noting that Hades (Pluto), son of Chronus and Rhea, like all the Olympians, was the brother of Zeus (Jupiter) and Demeter (Ceres). As the god of death, Pluto reigns over the underworld of the shades.

32 See Kieft (1994, p. 68), for Vasari’s criticism, and p. 67 for Benedetto Varchi’s negative comment.

33 See Athanassakis (1983/2004, 56), citing Hesiod's Theogony, pp. 969-974; Hansen (2005); Williams (1994); and on Pluto, https://religion.wikia.org/wiki/Pluto_(mythology)\#cite_note-7 (accessed August 15, 2019).
} 


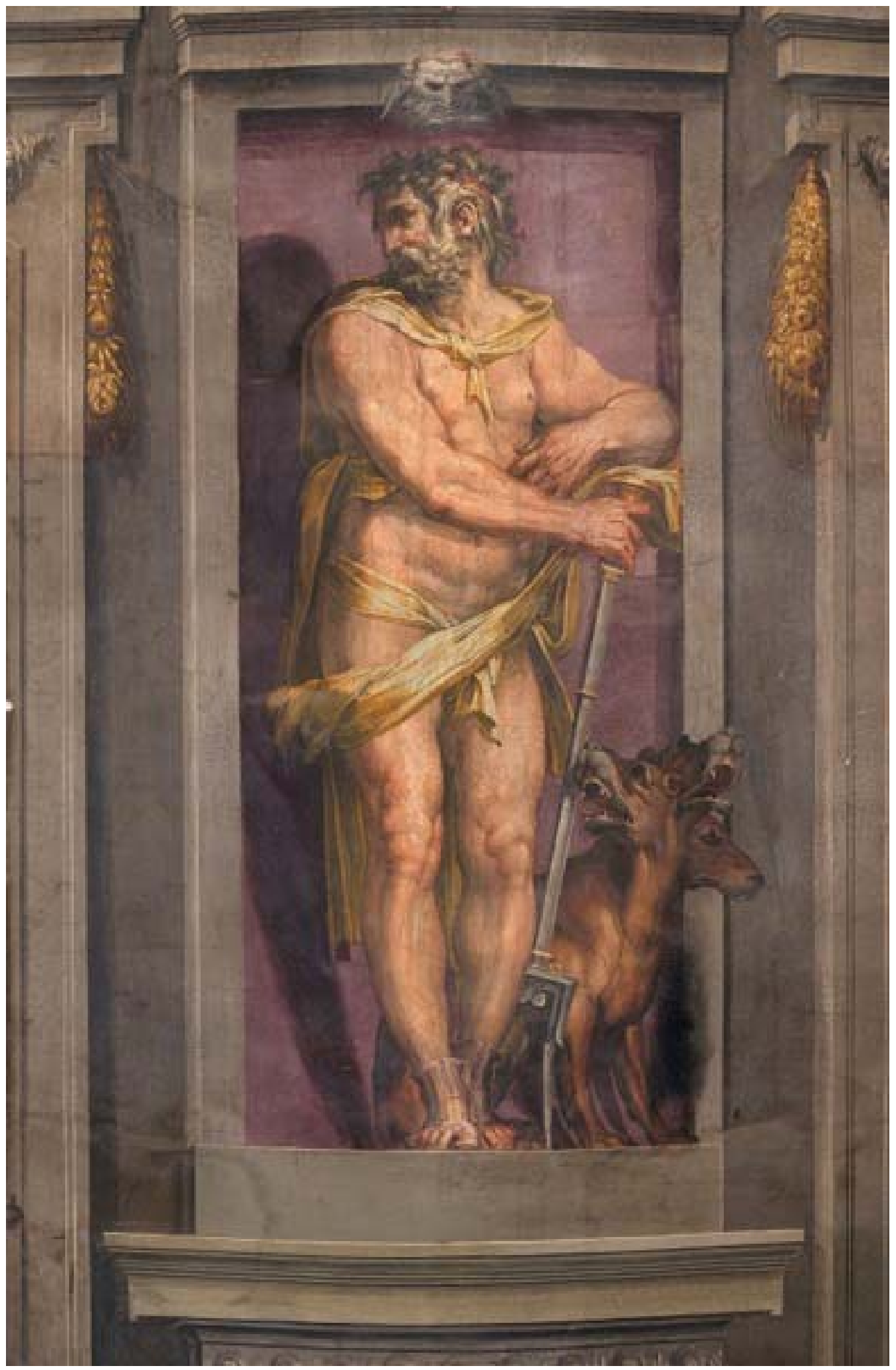

Figure 14. Giorgio Vasari and Cristofano Gherardi, Pluto, 1555-1556.

Window wall. Sala degli Elementi, Palazzo Vecchio, Florence.

Photo credit: HIP/Art Resource, NY. 
Not by accident does Mercury's prominent index figure point upward to the compartment in the ceiling above both images, bringing the attention of Pluto and the viewer to the depiction of the Personification of Sleep or Night (see Figure 15). The viewer is aware of Vasari's visual connection in the manner that the figures gesture and relate to each other. In his alcove, the figure of Pluto turns to observe the standing figure of Mercury, who dramatically points with his index finger towards the ceiling, directing Pluto to the resting personification of Night. In a reclining position, Night sleeps deeply. She is surrounded by attributes associated with symbols of night, such as an owl with wide-open eyes, a burning lamp, and theatrical masks resting on a platform. A cornucopia, “a horn of plenty”, with wintery fruits (apples and grapes and plums) alludes to the fertility riches provided by Pluto, god of fertility and the underworld (Athanassakis, 1983/2004). In his imagery, Vasari conflated two sculptural images: the Hellenistic representation of Sleeping Ariadne or Cleopatra (see Figure 16) (Liverani; 1999) ${ }^{34}$ and Michelangelo's monumental sculpture of Night for the Medici Chapel in San Lorenzo, Florence (see Figure 17) (Panofsky, 1962; Nitschke-Joseph, 2013). ${ }^{35}$ Vasari has depicted a dormant reclining figure, her slumbering body in a small lettuccio (reclining bed) with her hand holding her sleepy head. The personification of Night sleeps with her legs crossed, exposed nude shoulders, and veiled sagging breasts-a concealed-revealed classical motif in the treatment of drapery (compare Figures 15 and 16). Vasari has veiled Night by covering her golden tresses while placing on her hair a large half-moon brooch encircling a star-lunar symbols of night. This motif is borrowed from Michelangelo's Night along with the barn owl and resting masks (compare Figures 15 and 17).

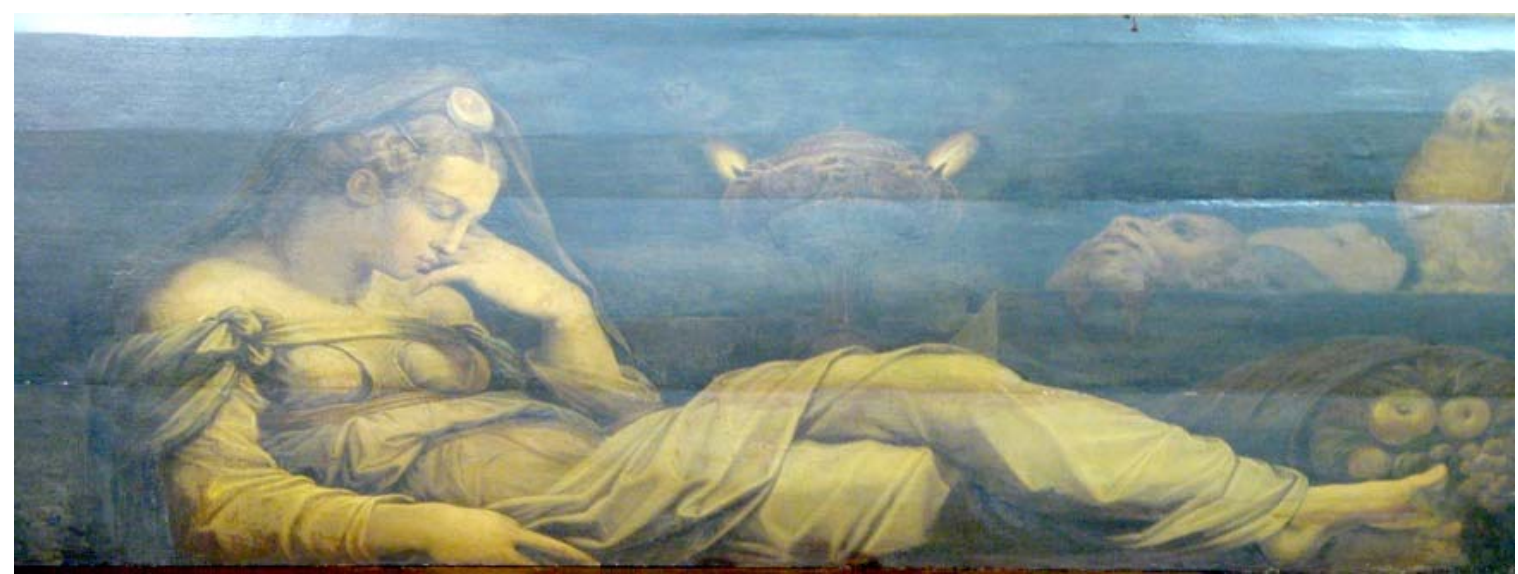

Figure 15. Giorgio Vasari and Cristofano Gherardi, Night or Sleep, 1555.

Window wall ceiling. Sala degli Elementi, Palazzo Vecchio, Florence.

Photo credit: author.

\footnotetext{
${ }^{34}$ In the Vite, Third Preface, Vasari referred to Pliny's impact by claiming that success came to the artists who followed, after they had seen some of the finest works of art mentioned by Pliny dug out of the earth during the Renaissance, namely, "The Laocöon, Hercules, the large Torso of Belvedere, as well as Venus, Apollo, Cleopatra, and countless others, all possessing the appeal and vigor of living flesh and derived from the finest features of living models”. Bettarini-Barocchi, Vasari, IV, p. 7; and Liverani (1999, pp. 21-29).

35 See https://www.ias.edu/ideas/2013/nitschke-joseph-panofsky (accessed December 15, 2015), noting Michelangelo’s assimilation of classical sculptures, in particular the Laocoön and the Torso Belvedere.
} 


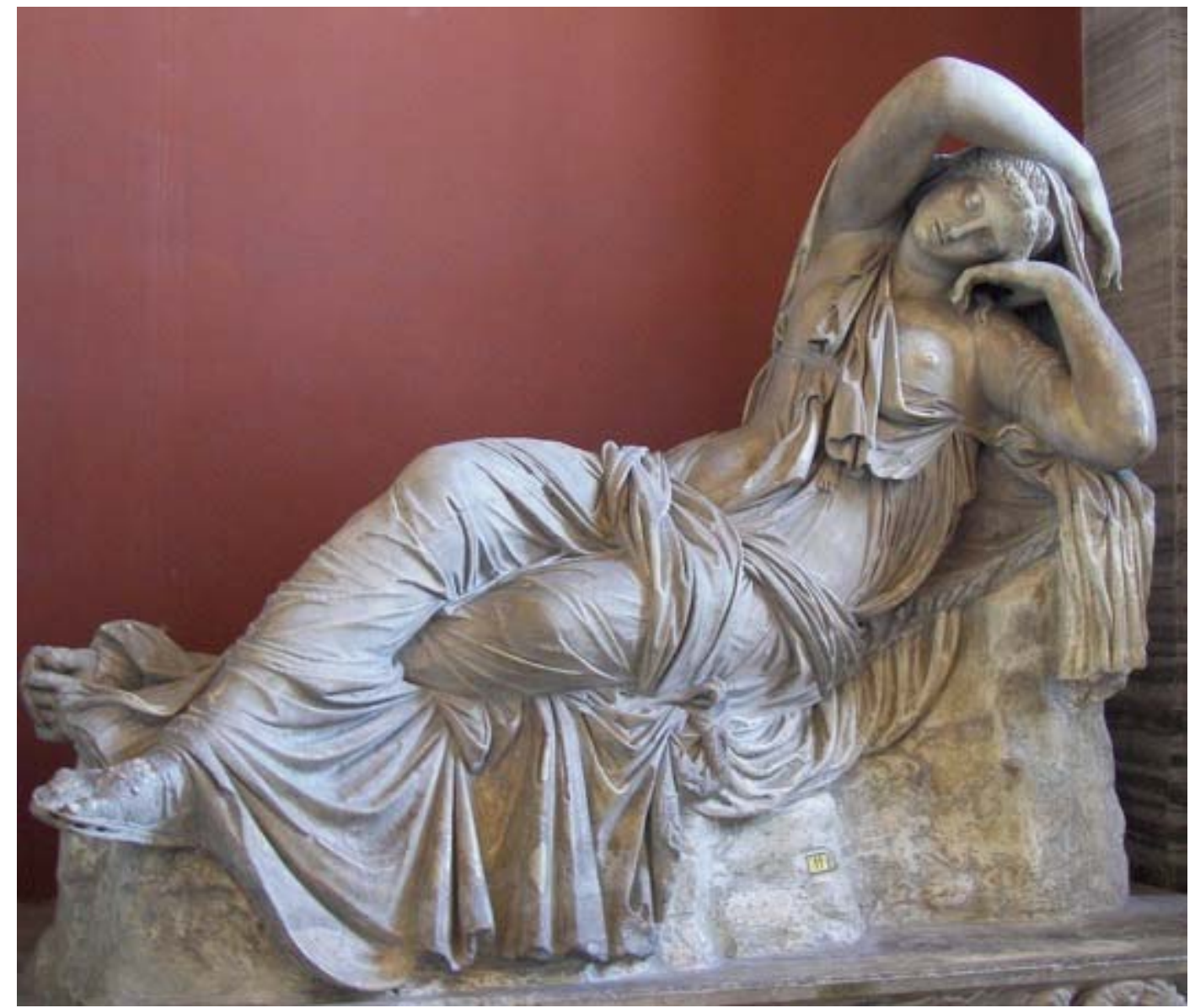

Figure 16. Sleeping Ariadne or Cleopatra, 2nd century BCE. Vatican Museum, Vatican City.

Photo credit: Public domain, Wikipedia.org. 


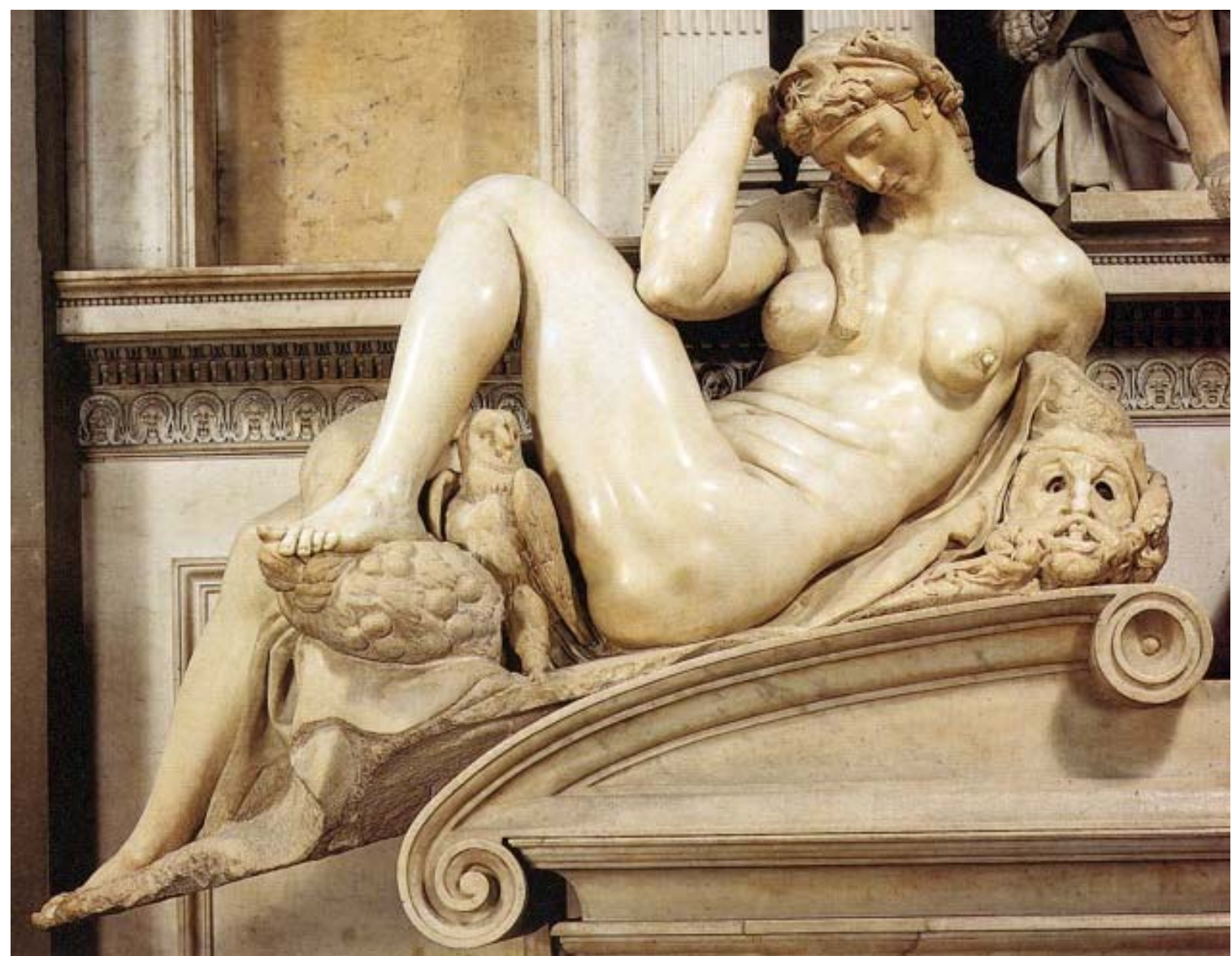

Figure 17. Michelangelo, Night, 1531. Tomb of Giuliano de’ Medici.

New Sacristy, San Lorenzo Church, Florence.

Photo credit: Public domain, Wikipedia.org.

In I Ragionamenti, First Ragionamento, Vasari explained to the Prince:

The personification [of Night] is across from the personification of Day... Under the benefits of the transit of the Chariot of the Moon, Night sleeps peacefully... Masks and lamps... a barn owl and bats are included in the scene.

(Il sonno della Notte quadro dirimpetto [al Giorno]...che dorma con gra quiete, che di questa ha cura il carro della Luna...maschere e lucerne...il barbagianni e i pistrelli orioli).

Paralleling the design of the lintel area in the niche of Mercury, Vasari depicted in Pluto's niche another type of owl, a nocturnal symbol, in the center of the lintel area.

The cosmological connections associated with Mercury derived from Roman mythology. Mercury, as one of the seven planetary gods, including the sun and moon, interacts with them as well, influencing every aspect of human life. Under this classical influence, Renaissance astrology views planetary Mercury as ruling the lower mind or a stage of perception and communication that succeeds a primordial impulse.

Vasari's manner of composing images for a program as a compendium of visual iconography parallels and derives from the literary practices and conceits of Vincenzo Cartari and Pierio Valeriano, his tutor. In turn, these humanist writers based their conceits on pagan philosophy and Christian theology, as manifested by the Renaissance philosopher, Marsilio Ficino, in De vita coelitus comparanda (How Life Should be Arranged 
According to the Heavens) (Ficino, 1489/1576/1959; Moore, 1990). The moral implication to live a good life is encountered in the mythographical and emblematic manuals as well as in the Neoplatonic treatises.

In the Renaissance, Marsilio Ficino, physician and philosopher for the Medici court, translated from the Greek into Latin a collection of texts known as the Hermetic writings (Scott \& Ferguson, 1936; Salaman, van Oyen, Wharton, \& Mahe, 2004). ${ }^{36}$ These anonymous texts, which were comprised of Egyptian writings on philosophy, astrology, alchemy, magic, and medicine, were brought to Florence from Greece and acquired by Cosimo de Medici in 1460. Ficino translated and published them with a commentary in 1471. Since Egypt is the setting for these mystical writings, Renaissance humanists thought that these writings contained divine revelations from the god Hermes or the Egyptian god Thoth. "Both gods were patrons of the art of writing, of sciences and of learning in general” (Joost-Gaugier \& Whitfield, 2001, p. 61). However, Greek awareness of the god Thoth dates from the time of Herodotus, and the Egyptian god was identified with his Greek counterpart, Hermes, “... and given the appellation Trismegistus, or thrice-great, signifying that he combined the function of king, philosopher and priest” (Whitfield, 2001, p. 145). Ficino strongly believed that Hermes was a historical figure from whom the great philosophical traditions of Greece descended, and “... he even wondered if Hermes or Thoth was Moses, presenting divine wisdom in another form and through another persona” (Whitfield, 2001, p. 146). Ficino commented,

As Plato wrote, it was a custom among the Egyptians to choose priests from among philosophers and kings from among the company of priests.... Being thus the first among philosophers, he Thoth-Hermes progressed from natural philosophy and mathematics to contemplation of the gods.... Hermes wrote many books having to do with the knowledge of divine things, in which lie revealed mysteries as arcane as his oracles are amazing. (Whitfield, 2001, p. 146)

Thus, Hermes-Mercury was considered the divine magician, the patron of grammarians and metaphysicians, and the revealer of secret knowledge. This arcane knowledge is called "hermetic", after the translation and dissemination of the ancient mystic texts attributed to Hermes Trismegistus, the thrice-great.

Vasari's Florentine Mercury is portrayed with his traditional caduceus and winged sandals and hat (see Figure 12). In addition to these traditional attributes, the flute attests to Mercury's involvement with the underworld (Cartari, 1963; Henkel \& Schöne, 1970/1978). ${ }^{37}$ In his analysis of Mercury, Ficino focused on the god's capricious powers associated with souls:

Mercury has the power to put souls to sleep or waken them with his staff; that is, in some way or another, by putting himself into a certain shape, he can dull or sharpen the mind, or weaken or strengthen it, or upset or calm it. (Ficino, 1489/1576/1959, p. 546)

This is one of the links between the Roman Pluto and Mercury, who leads the souls of the dead to Hades and conducts the embassies of Olympus. Mercury links the earth and the sky, the living and the dead (Vernant, 2001). As a divine messenger, he guides souls to the underworld as pyschopomp (a guide of souls), alluding to the travel of the soul from natural realm (the body or external appearance) back to the spiritual realm (inward reality) (Reid, 1993). ${ }^{38}$

\footnotetext{
${ }^{36}$ Hermes Trismegistus's Hermetica was considered in the Renaissance to be a mythical text of Egyptian origin dating to the second century CE.

${ }^{37}$ Vasari also appropriated Cartari's depiction of the planetary gods but adjusted his imagery to fit his decorative scheme. Thus, when comparing Cartari's deities with Vasari's planetary gods, visual assimilation and innovations are revealed. For instance, two of the Vasarian planetary gods, Mercury and Pluto, have additional attributes through which each was linked to a specific narrative.

${ }^{38} \mathrm{He}$ also served as emissary from the gods to mortals. For example, he guided Venus/Aphrodite to the Judgment of Paris, escorted Persephone (Proserpine) up from the underworld, and Psyche to Olympus.
} 
In his writings and visual programs, Vasari attributed some of Mercury's virtues, such as shrewdness in commerce and healing, to the assistance of gemstones. Vasari wrote to Duke Cosimo I:

[Cosimo] who is very mercurial, for his ability in negotiating with eloquent men, for his knowledge like Mercury, of mineral wealth and of sophistry and for his delight in subtle talk and for the number of men with whom he had conversed. (Muccini \& Cecchi, 1991, p. 57)

One of the earlier depictions of mercurial traits of the Medici was Botticelli's Primavera of 1475, at the Galleria degli Uffizi in Florence, where the messenger of the gods, Mercury, stirs the clouds with his staff. His red tunic is decorated with radiating flames, an alchemical symbol associated with his rapid motion (Cox, 1997, p. 260).

For Vasari, the imagery and symbolism of Pluto also reveals traits associated with Cosimo I's persona, in particular his healing and political powers.

A divinity with power over the mineral wealth of the earth without which the merchants are lost ... as would happen to me, for as much as I know how to make these rooms and even more beautiful ones, I could not do it without the money, the commodities and the riches of Duke Cosimo, prince of that wealth. (Muccini \& Cecchi, 1991, p. 57)

Both gods were also invoked for their use of mineralogy or gemology as a healing power. In the depiction of Mercury and Pluto in the Sala degli Elementi, Vasari revealed the fascination that Duke Cosimo I, and later his son Francesco, had for minerals and gems as well as their interest in alchemy. Duke Cosimo I commissioned two foundries: one in the basement of the Palazzo Vecchio and the other in the Uffizi. Duke Cosimo I manipulated minerals and metals in the laboratory of the foundries, in particular, separating, diluting, and preparing mercury. This love for alchemy is a Medicean trait. A hundred years earlier, Cosimo de' Medici requested Marsilio Ficino to translate Pimandro, a text attributed to Hermes Trismegistus (Scott \& Ferguson, 1963). Ficino titled the translation Mercurii Trismegisti liber de potestae et sapientia Dei (The Book of Mercury Trismegistus Concerning the Power and Wisdom of God). In the Medicean library, there were also the following books: Basilio Lapi's Libro de' minerali et distillatini, Giordano Bruno's La trasmutazione dei metalli, and Tommaso Campanella’s La practica dell' estasi filosofica (Le Mollé, 1995; Orlandi, 1978).

The connection of these two images, Mercury and Pluto, with Duke Cosimo I is significant. As noted earlier, the duke had a passion for ancient artifacts, especially Etruscan. In 1560, after the conquest of Siena, the Duke visited Rome for the first time during his triumphal pilgrimage. His encounter with antiquity was such that he expanded his passion for collecting Etruscan art to ancient art. On his return from Rome, the Duke landed in Livorno with seven ships containing classical statues purchased during his sojourn in the eternal city (Le Mollé, 1995). In addition, from the extensive papal collection of classical sculptures in the Cortile Belvedere, Paul IV offered to the Florentine Duke the statues of Dying Alexander, Wild Boar, two fragmented statues of Pasquino, and, most significant to Florence and the Medici's symbolism, Hercules and Antaeus and Hercules and Cerberus (Gregori \& Heikamp, 1997). ${ }^{39}$ These precious sculptures were transported to Florence (Haskell \& Penny, 1981; Le Mollé, 1995). ${ }^{40}$ For Pluto’s image, Vasari quickly appropriated the stylistic qualities of the newly acquired statue of Hercules and Antaeus and Hercules and Cerberus. He was aware of

\footnotetext{
39 The statue from Rome arrived in Florence in 1564 and was placed in the Pitti garden. In 1621 was heavily restored.

40 See Haskell and Penny (1981), some of these statues were placed in the Palazzo Pitti, recently acquired by Cosimo I's wife, Eleanora. One of the Pasquino statues became part of a fountain in the Ponte Vecchio. See also Le Mollé (1995, p. 233), a sarcophagus is also included.
} 
the importance of this statue since it was so admired in the High Renaissance; in 1510, it was attributed to the ancient sculptor Polyclitus (Haskell \& Penny, 1981). ${ }^{41}$ Vasari’s contemporary sources for Pluto were the Florentine sculptures of Baccio Bandinelli, Hercules and Caucus of 1525-1534, and Bartolomeo Ammannati’s Neptune of 1559-1563, in the Piazza della Signoria (compare Figures 14 and 18).

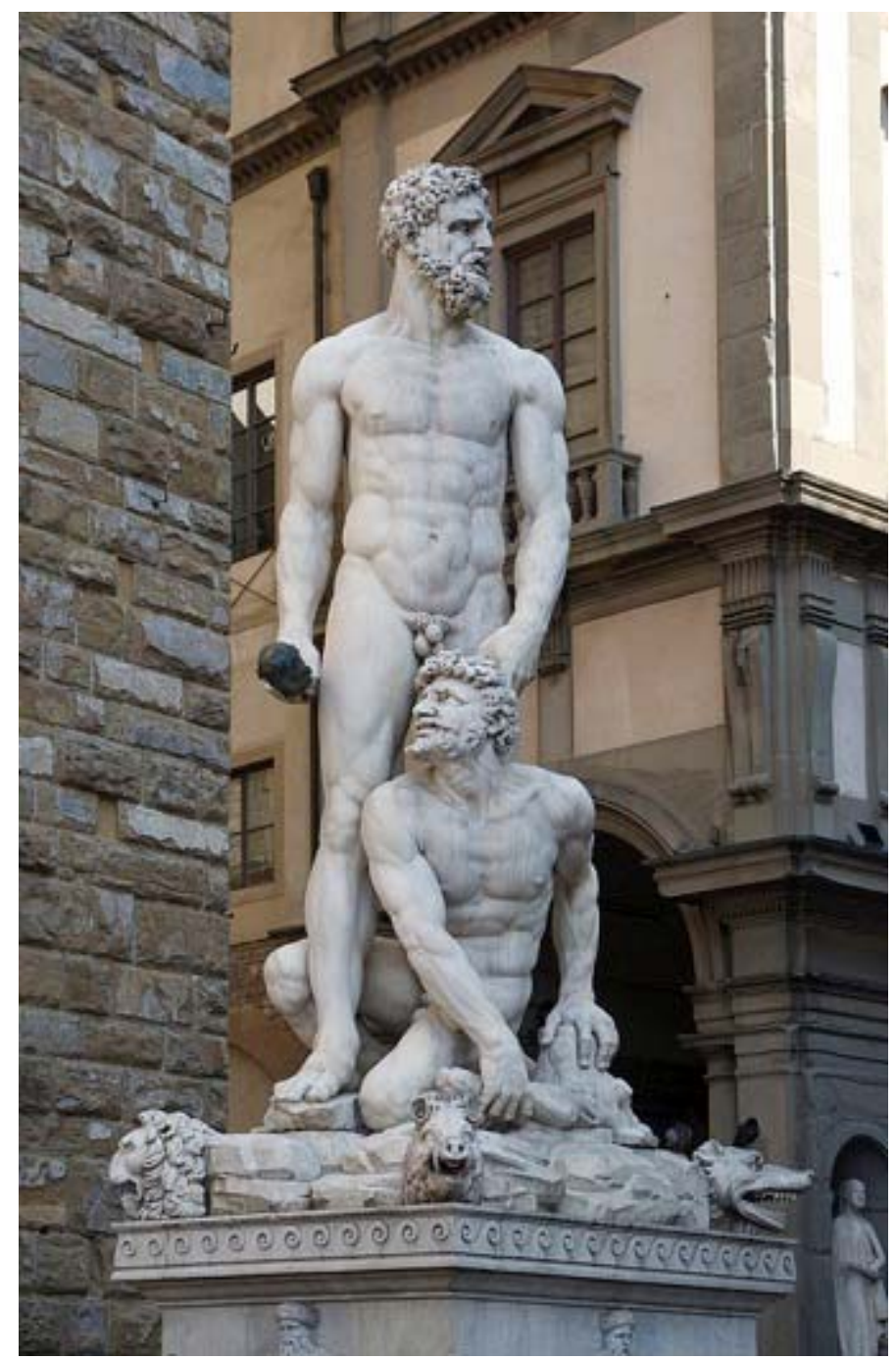

Figure 18. Baccio Bandinelli, Hercules and Cacus, 1525-1534.

Piazza della Signoria, Florence.

Photo credit: Public dominion, Wikipedia.org.

The large size of the images of Mercury and Pluto suggests as well Vasari’s intention to consider them as simulated sculptures, honoring and recalling the duke's recent artistic acquisitions. ${ }^{42}$ In 1567, the Duke acquired 14 more antique statues for his collection at the Uffizi gallery and Palazzo Pitti. He then contacted the humanists, Paolo Giovio and Pietro Aretino, and sought Vasari's assistance in obtaining from them more

\footnotetext{
${ }^{41}$ In 1518, Italian sculptor Antico claimed that this statue was the "most beautiful work of antiquity that ever was". With this spirit of admiration, he completed a small copy in bronze for the grotto of Isabella d'Este (now in the Kunsthistorisches Museum of Vienna).

42 Perhaps in view of the origin and history of these statues and their assimilation in Vasari's imagery, one may suggest that these two works were painted after the room was completed, not before 1565.
} 
classical sculptures. Vasari obtained small bronze statues for the duke's cabinet in the Palazzo Vecchio (Conticelli, 2007; Masinelli, 1991). ${ }^{43}$

The association with Mercury and Pluto relates at two levels to Duke Cosimo I. Aesthetically, they relate to the Duke's passion for ancient art, since these two Vasarian paintings relate to classical sculptures acquired by Duke Cosimo I for his Medicean collection at the Uffizi and Palazzo Pitti. The other connection is symbolic in nature. The cosmological and magical qualities attributed to the Mercury and Pluto are linked with Cosimo's persona as well as with his interests and pursuits in astrology, alchemy, and gemology.

In the depiction of Mercury and Pluto in the Sala degli Elementi, Vasari revealed the fascination that the Medicean family, including Cosimo I and later his son Francesco, had for minerals and gems as well as an interest in alchemy (Aakhus, 2008; Maresca, 2012; Orlandi, 1978; Slavenburg, 2012).

Appropriately, Vasari honored his patron, Cosimo I de’ Medici, and connected the mercurial and plutonian forge with the duke's recent building of the two foundries. Both foundries were originally located in the basement of the Palazzo Vecchio, but after Vasari's complaint that "fuoco e fumo dannegianodo I nuovi Quartiere appena creato (fire and smoke are damaging the new apartments [Sala degli Elementi] that I just created)" (Berti, 1967, p. 51), one of the foundries was moved to Boboli Gardens, and the other to the basement of the Uffizi (Berti, 1967; Maresca, 2012).

Although Mercury was Cosimo I's astral birth sign and Gemini is his zodiac sign, the Duke appropriated the sign of Capricorn to affiliate himself with the ancient Roman emperor Augustus and the present emperor, Charles V, both of whom were born under the astral sign of Capricorn and the planetary governance of Saturn (Crum, 1988; van Veen, 2006, Cheney, 2012b). Not by accident, Vasari depicted the images of Mercury and Pluto facing the wall depicting Vulcan's Forge, associating the Mercurial element of fire and Mercury's cosmic power with his own wall of the Element of Fire (Cheney, 2014).

Cosimo I, born under the tutelage of the planet Mercury, was a member of the "Children of Mercury". Hence, he was favored and protected by the planetary god as well as manifesting similar tendencies and passions for magic, ability in commerce, and prudence in governance. From Mercury, Cosimo I was granted the gift of wisdom for understanding the mysteries of the cosmos. As noted in the Hermetica, when the planetary gods were offering their gifts to the terrestrial individuals, Mercury presented to them the following:

I will make [individuals] men's nature well endowed; I will devote to them prudence and wisdom, persuasiveness and truth, and never will I cease from congress with invention, but ever will I benefit the mortal life of men [individuals] born underneath my types of life. For that the types of our Father and Creator had set apart for me, are types of wisdom and intelligence, and more than ever-is this so-what time the motion of the stars set over then doth have the natural of each consonant with itself. And God, the Master of the universe, rejoiced and hearing this, and ordered that the race of men [individuals] should be. (Ehlert, 2019b; Curran, 2007, pp. 10, 13, 90-91, 123) ${ }^{44}$

\footnotetext{
${ }^{43}$ See Conticelli (2007) and Masinelli (1991, pp. 9-21), for inventories of some of the objects in the Scrittorio of Calliope and objects transferred to this location from Francesco I Studiolo (Guardaroba).

${ }^{44}$ I am grateful to Ehlert (2019b), citing this passage from the Hermetica in Brian Brown (1923/2010). See Curran (2007), pp. 10, 13, 90-91, and 123, on the reception and significance of Ficino's Hermetica.
} 


\section{Conclusion}

In this short essay, the author has not discussed the thematic connection between the imagery of Mercury and Pluto on the window wall and the rest of the narrative on the other walls and ceiling, but as a note in $I$ Ragionamenti, Vasari and his friendly advisors, Bartoli and Giovio, connected the whole program of the chamber with the purpose of aggrandizing and honoring their patron, Cosimo I de' Medici, as well as themselves for inventing such a magnificent history painting in an apartment of a Medicean palace.

Metaphorically, these two colossal simulated statues of Mercury and Pluto stand as sentinels to the entrance of the Duke's Sala degli Elementi. Pluto's Cerberus and Mercury's caduceus are vigilant and wise custodians to the magical and spiritual powers imparted by the pantheon of the gods residing in this sala. These personifications are also visually connected with some of the imagery located perpendicularly on the floor below, the Sala of Leo X. Fortuitously or planned, Vasari's statuesque figures of Mercury and Pluto in the Sala degli Elementi echo the standing figures portraying the Medicean dukes, Alessandro de' Medici (1511-1537) ${ }^{45}$ and Cosimo I de' Medici (1519-1574), respectively, a floor below in the Sala di Leo X (see Figures 19, 20, and 21). The dukes' contrapposto stances, the heroic treatment of their persona-elaborate military attire-and corresponding Medicean attributes bond them with the pagan gods above them. Perhaps Vasari connected the volatile nature of the astral god Mercury with Alessandro's explosive conduct, and Cosimo I's alchemical skills with the mining mastery of Pluto (compare Figures 1 and 21; Figures 12 and 19; and Figures 14 and 20). Situated in similar niches, the dukes stand in honorific attires as they bear witness to the historical battles and sagas visualized on their adjacent walls. Like their corresponding pagan gods placed on the floor above them, the dukes as rulers of Florence guard Medicean history and Florentine culture. In this manner, Vasari continued to honor the Medicean family lineage as patrons of the city, messengers of good will, and protectors of the Florentine patrimony (Gregori \& Heikamp, 1997).

Between 1569 and 1570, Vasari and his assistants painted other chambers in Palazzo Vecchio honoring the treasures of the Medicean family, such as Cosimo I's Tesoretto and Francesco I's Studiolo. These private rooms housed the precious gems, gold, and other precious materials of the Dukes of Tuscany (Berti, 1967; Schaefer, 1976; Conticelli, 2007; Maresca, 2012; Cheney, 2019b). Several years before, Francis’s father, Cosimo I, had requested that Vasari paint the Sala degli Elementi, where the seeds for the iconography of the elements were established. Thus, the cosmological and magical qualities attributed to Jupiter, Venus, Saturn, Apollo, Mercury, and Pluto were linked to the Medici family, in particular to Cosimo I's persona as well as with his interests in astrology, alchemy, and gemology (Maresca, 2012; Orlandi, 1978). On another level, Vasari's imagery attests to his invenzione for creating history paintings in a ducal chamber, confirming him as an advocate for Medicean culture.

\footnotetext{
${ }^{45}$ Known as Il Moro for his dark complexion, Alessandro became Duke of Florence in 1532. He was an illegitimate child of Cardinal Giulio de’ Medici (Pope Clement VII), who ironically was assassinated for his violent conduct by his distant cousin, Lorenzaccio de’ Medici. Alessandro commissioned Bandinelli’s Hercules and Caucus, a visual source for Vasari’s depiction of Pluto.
} 


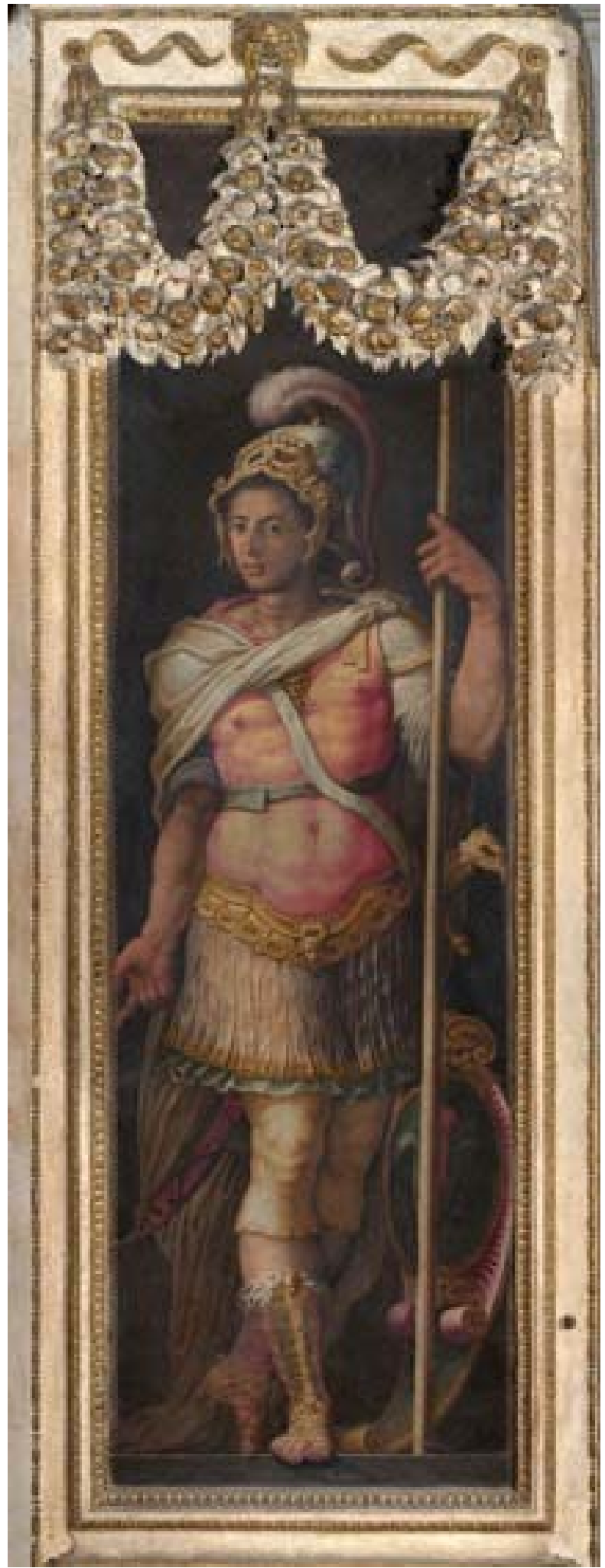

Figure 19. Giorgio Vasari, Alessandro de 'Medici (Il Moro), 1555-1562. Sala di Leone X, Palazzo Vecchio, Florence. Photo credit : HIP/Art Resource, NY. 


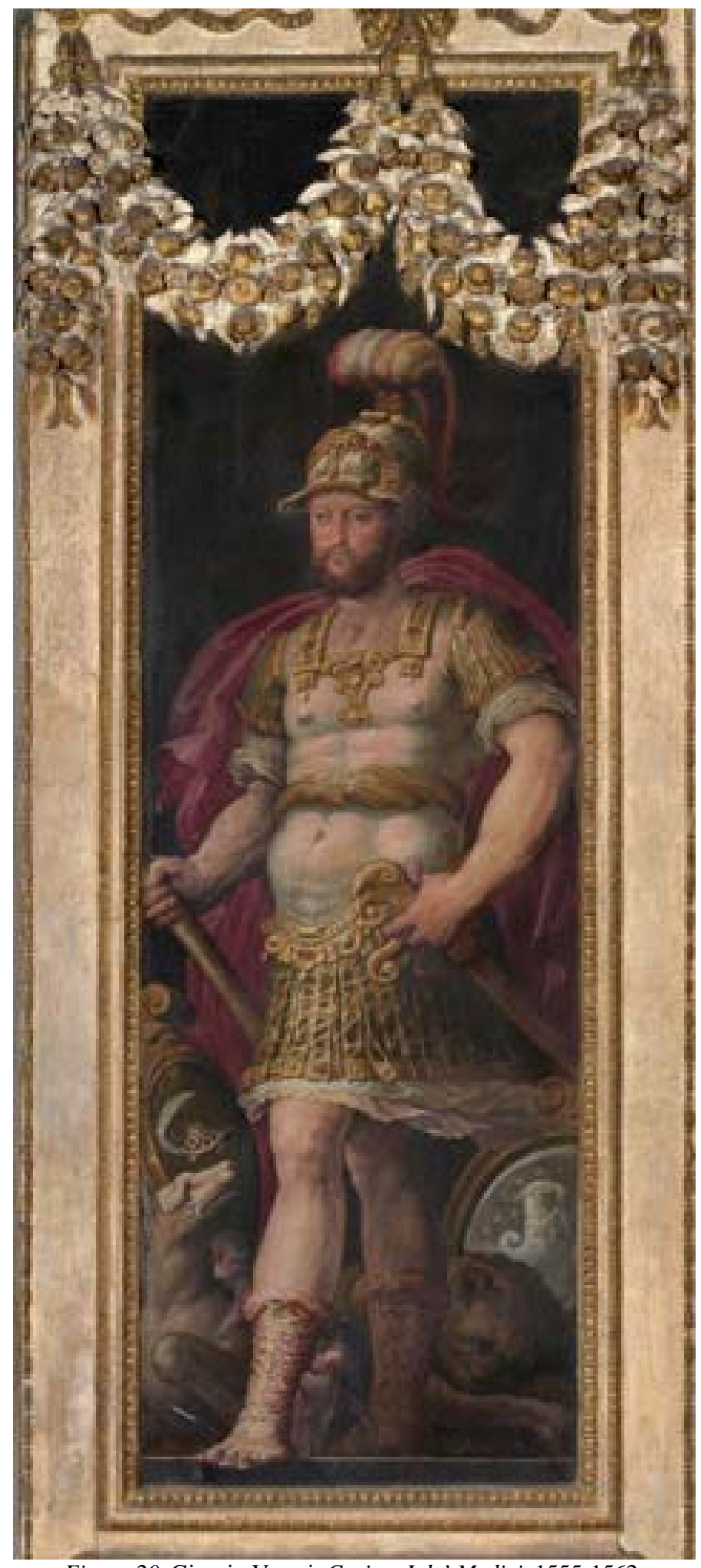

Figure 20. Giorgio Vasari, Cosimo I de’ Medici, 1555-1562. Sala di Leone X, Palazzo Vecchio, Florence. Photo credit : HIP/Art Resource, NY. 


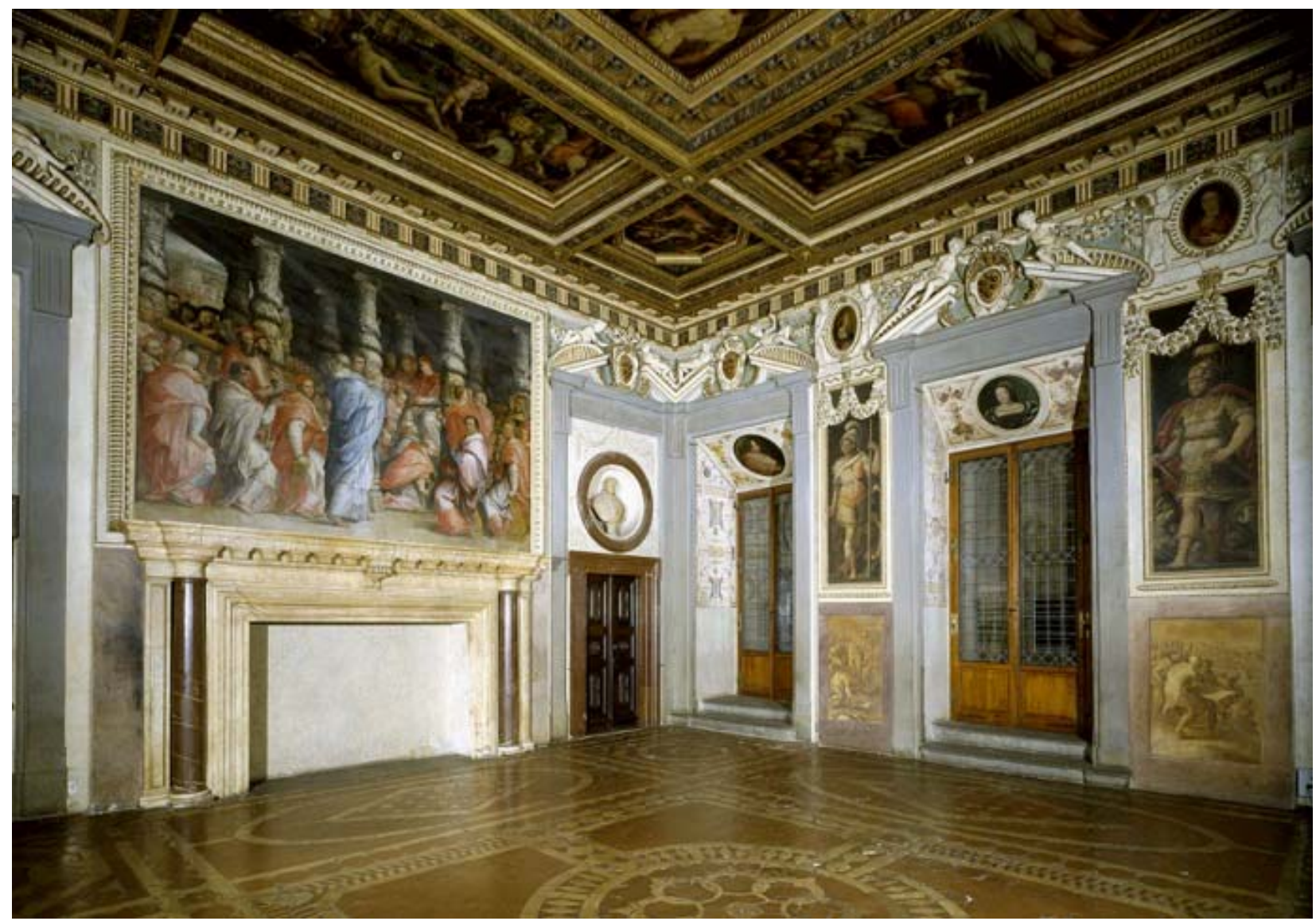

Figure 21. Giorgio Vasari, View of the Medici Dukes, 1555-1562.

Sala di Leone X, Palazzo Vecchio, Florence.

Photo credit: Scala/Art Resource, NY.

\section{References}

Aakhus, P. (2008). Astral magic in the Renaissance: Gems, poetry, and patronage of Lorenzo de' Medici. Magic, Ritual, and Witchcraft, 3(2), 185-206.

Allegri, E., \& Cecchi, A. (1980). Palazzo Vecchio e i Medici: Guida storica (Old Palace and the Medici: Historic guide). Florence: S.P.E.S.

Allen, M. J. V., Rees, V., \& Davies, M. (2002). Marsilio Ficino: His theology, his philosophy, his legacy. Leiden: Brill.

Athanassakis, A. N. (1983/2004). Hesiod: Theogony, works and days, shield. Baltimore, MD: John Hopkins University Press.

Barlow, P. (2005). The death of history painting in the nineteenth century? Visual Culture in Britain, 6(1), 1-13.

Barocchi, P., \& Ristoi, R. (Eds.). (1965/1983). Il Carteggio di Michelangelo (The letters of Michelangelo, Vols. 5). Florence: Sansoni.

Bartoli, C. (1567). I Ragionamenti accademici (Academic dialogues). Venice: F. Lorenzini da Turino.

Baxter, P. T. (1985). Rileggendo i ragionamenti (Rereading the dialogues). In G. C. Garfagnini (Ed.), Giorgio Vasari: Tra decorazione ambientale e storiografia artistica (Giorgio Vasari: Between environmental decoration and artistic historiography (pp. 83-93). Florence: Leo S. Olschki.

Berti, L. (1967). Il principe dello Studiolo: Francisco I (The prince of the Studiolo: Francis I). Florence: Edam.

Bettarini, R., \& Barocchi, P. (Eds.). (1971/1986). Giorgio Vasari, le vite de’ più eccellenti architetti, pittori, et scultori (Giorgio Vasari, the lives of the most excellent architects, painters and sculptors). Florence: Sansoni.

Bolzoni, L., \& Volterrani, S. (Eds.). (2008). Con parola breve e con figura: Emblemi e imprese fra antico e moderno (With a short word and a short image: Emblems and imprese between ancient and modern). Pisa: Edizioni della Normale. 
Brown, B. (1923/2010). The wisdom of the Egyptians: The story of the Egyptians, the Religion of the Ancient Egyptians, the Ptah-Hotep and the Ke'gemini, the book of the dead, the wisdom of Hermes Trismegistus, Egyptian magic, the book of Thoth. New York: Cosimo, Inc. Retrieved September 30, 2019, from https://babel.hathitrust.org/cgi/pt?id=miun.agw3164.0001.001\&view=1up\&seq=5

Brown, C. M. (1993). Our accustomed discourse on the antique: Cesare Gonzaga \& Gerolamo Garimberto, two Renaissance collectors of Greco-Roman art. London: Routledge.

Brown, M. (2014). Visioning the planets in 15th century Florentine printmaking. Prints from the British Museum, Visual Pursuits (June). Retrieved from https://visualpursuits.org/2014/06/26/visioning-the-planets-in-15th-century-florentine-printmaking/

Bryce, J. (1983). Cosimo Bartoli (1503-1572). Geneva: Droz.

Cartari, V. (1963). Imagine delli Dei de gl'antichi (Images of the Gods of the ancients). Graz: Akademische Druck und Verlagsanstal.

Cecchi, A. (1997). Pratica, fierezza e terribilità nelle grottesche di Marco da Faenza in Palazzo Vecchio a Firenze (Practice, pride, and dareness in the grotesques of Marco da Faenza in the Old Palace in Florence). Paragone, 327(28), 6-26, 24-54, 329.

Cecchi, A. (2011). Bartoli, Borghini, e Vasari nei lavori di Palazzo Vecchio (Bartoli, Borghini, and Vasari in the works of the Old Palace). In C. Bartoli (Ed.), Francesco Paolo Fiore and Daniele Lamberini (pp. 283-296). Florence: Olschki.

Chastel, A. (1975). Marsile Ficin et l'art (Marsilio Ficino and art). Geneva: Droz.

Cheney L. D. (2018). Giorgio Vasari's planetary journey. In S. Lippert (Ed.), Artistic responses to travel in the Western tradition (pp. 21-31). New York: Routledge.

Cheney, L. D. (2000). Giorgio Vasari's planetary gods in the chamber of fortune. In R. E. White (Ed.), The Inspiration of astronomical phenomena (pp. 25-35). Tempe, AZ: University of Arizona Press.

Cheney, L. D. (2003). Giorgio Vasari's Neoplatonic cosmology: The planets. In L. Cheney (Ed.), Neoplatonic aesthetics: Music, literature and the visual arts (pp. 227-249). London: Peter Lang.

Cheney, L. D. (2006). The homes of Giorgio Vasari. London: Peter Lang Publishers.

Cheney, L. D. (2007). Giorgio Vasari's teachers: Sacred and profane art. London: Peter Lang Publishers.

Cheney, L. D. (2009a). Giorgio Vasari’s Sala degli Elementi: The symbolism of water. Discovery, 26(2), 1-10.

Cheney, L. D. (2009b). Giorgio Vasari: Sala degli Elementi. The Sixteenth Century Studies International Conference, May 28-31, Geneva, Switzerland.

Cheney, L. D. (2011a). Giorgio Vasari's artistic and emblematic manifestations. Washington, D.C.: New Academia Publishing.

Cheney, L. D. (2011b). Giorgio Vasari's element of earth. Renaissance Society of America, April 5-10, Montreal, Canada.

Cheney, L. D. (2012a). Giorgio Vasari’s prefaces: Art and theory. London: Peter Lang Publishers.

Cheney, L. D. (2012b). Il Corridoio Vasariano: A resplendent passage to Medici and Vasari’s grandeur. In P. Emmos, J. Hendrix, \& J. Lomholt (Eds.), The cultural role of architecture: Contemporary and historical perspectives (pp. 27-38). London: Routledge.

Cheney, L. D. (2014). Giorgio Vasari’s Vulcan's Forge, Sala degli Elementi in the Palazzo Vecchio: The symbolism of fire. Iconocrazia (June). Retrieved from http://www.iconocrazia.it

Cheney, L. D. (2015a). Giorgio Vasari’s “Sala degli Elementi” in Palazzo Vecchio, Florence: The symbolism of Saturn as heavenly air. In N. Campion (Ed.), Heavenly discourses (pp. 14-24). Bristol, UK: Sophia Centre Press.

Cheney, L. D. (2015b). Giorgio Vasari’s Vulcan's Forge, Sala degli Elementi in the Palazzo Vecchio: The Symbolism of Fire. Iconocrazia. Retrieved from http://www.iconocrazia.it/giorgio-vasaris/

Cheney, L. D. (2016). Giorgio Vasari’s Saint George: A Christian liberator. Notes on Early Modern Art, 3(2), 1-9.

Cheney, L. D. (2019a). Giorgio Vasari’s Neptune as Cosimo I de’ Medici: The element of water as a political symbol. In P. D. del Coral (Ed.), The iconography of water (pp. 30-40). Lisbon: University of Lisbon, CHAM.

Cheney, L. D. (2019b). An Alchemical Heaven: The Studiolo Ceiling of Francesco I de’ Medici. In L. Zirpolo (Ed.), Esotericism in Europe (pp. 297-330). New Brunswick: University of Rutgers.

Chevalier, J., \& Gheerbrant, A. (1994). A dictionary of symbols. London: Blackwell.

Chong, A. (Ed.). (2003). Raphael, Cellini, and a Renaissance banker: The patronage of Bindo Altoviti. Boston, MA: The Isabella Stewart Gardner Museum.

Combet-Farnoux, B. (1980). Mercure romain: Le culte public de Mercure et la fonction mercantile à Rome de la République archaïque à l'époque augustéenne (Roman Mercury: The public cult of Mercury and the mercantile function in Rome from the Archaic Republic to the time of Augustus). Rome: École française de Rome. 
Conticelli, V. (2007). Guardaroba di Cose Rare et Preziose: Lo Studiolo di Francesco I de' Medici, Arte, Storia e Significati (The cabinet of rare and precious objects: The studiolo of Francis I). Lugano: Agora Publishing.

Cox, R. (1997). The pillar of celestial fire: The lost science of the ancient seers rediscovered. Fairfield, IO: Sunstar Publishing.

Crum, R. J. (1988). Cosmos, the world of Cosimo: The iconography of the Uffizi Façade. The Art Bulletin, 71(2), 237-253.

Curran, B. (2007). The Egyptian Renaissance: The afterlife of ancient Egypt in early modern Italy. Chicago, ILL: The University of Chicago Press.

Del Vita, A. (1938). Il Libro delle Ricordanze di Giorgio Vasari (Giorgio Vasari’s book of records). Rome: Istituto D’archeologia e Storia Dell'arte.

Draper, J. (1973). Vasari’s decorations in the Palazzo Vecchio: The Ragionamenti (Vols. 2) (Ph.D. dissertation, University of North Carolina, University Microfilm).

Ehlert, J. B. (2019a). Mercury, Medici, and magic: Florence as the Children of Mercury in the Baccio Baldini's Children of the Planet series. Oral presentation at the South-Central Renaissance Conference, April 9-11, Texas Tech University, United States

Ehlert, J. B. (2019b). Chosen ones: Mercury and the concept of gnosis in Baccio Banldini’s “Children of Mercury” (Essay for Salve Regina University, RI).

Evelyn-White, H. G. (Trans.). (1914). Homeric Hymns 4 (Hermes). Cambridge, MA: Harvard University Press.

Faulkner, A., Vergados, A., \& Schwab, A. (2016). The reception of the Homeric Hymns. Oxford: Oxford University Press.

Ficino, M. (1489/1576/1959). De vita coelitus comparanda as Opera Omnia (Vols. 2). Turin: Bottega D’Erasmo.

Fiorenza, G. (2008). Dosso Dossi: Paintings of myth, magic, and the antique. Philadelphia: The Pennsylvania University Press.

Frey, K. (1923/1930). Der literarische Nachlass Giorgio Vasaris (Giorgio Vasari’s letters, Vols. 2). Munich: George Müller.

Gabriele, M., Galassi, C., \& Guerrini, R. (2013). L'Iconologia di Cesare Ripa: Fonti Letterarie e Figurative dall'Antichità al Rinascimento (The iconology of Cesare Ripa: Literary and visual sources from Antiquity to the Renaissance). Florence: Olschki.

Gáldy, A. M. (2009). Cosimo I de'Medici as collector: Antiquities and archaeology in the sixteenth century Florence. Cambridge: Cambridge Scholars Publishing.

Geronimus, D., \& Waldman, L. A. (2003). Children of Mercury: New light on the member of the Florentine Company of St. Luke (1475-1525). Mitteilungen des Kunsthistorischen Institutes in Florence, 47(1), 118-158.

Giani, E. (Ed.). (2011). Ragionamenti del Signor Giorgio Vasari: Sopra le invenzioni da lui dipintie in Firenze nel Palazzo Vecchio (The dialogues of Giorgio Vasari: On his inventions painted in Florence in the Old Palace). Florence: Barbès Editore.

Gregori, M., \& Heikamp, D. (1997). Magnificenza alla corte Medici. Milan: Electa.

Hansen, W. (2005). Classical mythology: A guide to the mythical world of the Greens and Romans. Oxford: Oxford University Press.

Härb, F. (2015). The drawings of Giorgio Vasari (1511-1574). Rome: Ugo Bozzi.

Haskell, F., \& Penny, N. (1981). Taste and the antique. London: Yale University Press.

Henkel, A., \& Schöne, A. (1970/1980). Emblemata: Handbuch zur Sinnibildkunst des XVI. und XVII. Jahrhunderts (Emblems: A manual on the symbols of art from the XVI century until the XVII century). Stuttgart: J. B. Metzler.

Hillard, C. (2013). Vasari and the Etruscan manner. The Sixteenth Century Journal, 44(4), 1021-1040.

Hind, A. M. (1938). Early Italian engravings: A critical catalogue with complete reproduction of all the prints (Vols. 2). London: M. Knoedler.

Humfrey, P., \& Lucco, M. (Eds.). (1988). Dosso Dossi: Court painter in Renaissance Ferrara. New York: Metropolitan Museum of Art.

Jackobs, F. (1984). Vasari's vision of the history of painting: Frescoes in the Casa Vasari, Florence. The Art Bulletin, 66(3), 399-416.

Joost-Gaugier, C. L. (2009). Pythagoras and the Renaissance Europe: Finding heaven. Cambridge: Cambridge University Press.

Kaske, C. V., \& Clarke, J. R. (Eds.). (1489/2002). De vita libri tres (Three books of life). Tempe, AZ: The Renaissance Society of America.

Kieft, G. (1994). The brain of Michelangelo: Art, art theory and the construction of the statue in Italian Renaissance (Ph.D. dissertation, Utrecht University).

Kliemann, J. (1978). Zeichnugsfragmente aus der Werkstatt Vasaris und ein unbekanntes Programme Vincenzio Borghinis Invenzioni per Pitture Fatte. Jahrbuch der Berliner Museen, 20, 57-208. 
Le Mollé, R. (1995). Giorgio Vasari: L’homee des Médicis (Giorgio Vasari: The Medici’s man). Paris: Grasset.

Le Mollé, R., \& Canfora, D. (Eds.). (2007). Giorgio Vasari, Ragionamenti di Palazzo Vecchio (Giorgio Vasari, The dialogues for the Old Palace). Paris: Les Belles Lettres.

Lippmann, F. (1895). Die sieben Planeten (The seven planets). Berlin: Internationale Chalkographische Gelleschaft.

Liverani, P. (1999). Il Cortile delle Statue in Belvedere (The sculptures in the Belvedere courtyard). In V. Brinkmann (Ed.), Il Torso del Belvedere: da Aiace a Rodin (The Belvedere Torso: From Aiace to Rodin) (pp. 21-29). Rome: Musei Vaticani.

M.C. (2008). Iconografia Di Pianeti e Figli (The iconography of the planets and the children). Italianistica: Rivista Di Letteratura Italiana, 37(3), 234-235. Retrieved from https://www.jstor.stable.org/stable/23937949

Maffei, M. (2009). Le radice antiche dei simboli: Studi sull'iconologia di Cesare Ripa e i suoi rapporti con l'antico (The ancient roots of symbols: Studies about the iconologia of Cesare Ripa and his relation with antiquity). Naples: La Stanza delle Scritture.

Maresca, P. (2012). Alchimia, magia e Astrologia nella Firenze dei Medici (Alchemy, magic, and astrology in the Medicean Florence). Florence: Angelo Pontecorboli.

Martin, R. P. (2003). Myths of the ancient Greeks. New York: New American Library.

Masinelli, A. M. (Ed.). (1991). Bronzetti e anticaglie dalla Guardaroba di Cosimo (Bronzes and antiques in the Cosimo's Cabinet). Florence: S.P.E.S.

Mazzuchelli, G. M. (1753/1760). Gli Scrittori d'Italia (The Italian writing chambers, Vols. 2). Brescia: Bossini.

Milanesi, G. (Ed.). (1879/1885/1970). Giorgio Vasari, Le vite de’ più eccellenti pittori, scultori ed architettori (1568) (The lives of the most excellent Italian painters, sculptors and architects, 1568, Vols. 9). Florence: G. C. Sansoni.

Moore, T. (1990). The planets within: The astrological psychology of Marsilio Ficino. Hudson, NY: Lindsfarne Press.

Muccini, U. (1990). Il Salone dei Cinquecento in Palazzo Vecchio. Florence: Le Lettere.

Muccini, U., \& Cecchi, A. (1991). The apartments of Cosimo in Palazzo Vecchio. Florence: Le Lettere.

Nitschke-Joseph, U. (2013). A fortuitous discover: An early manuscript by Erwin Panofsky reappears in Munich in 2013. Retrieved from http://www.ias.edu/nitschke-joseph-manuscript

Orlandi, G. L. (1978). Cosimo e Francesco de' Medici alchimisti (Cosimo and Francis de' Medici alchemists). Florence: Nardini.

Pallottino, M. (1977). Vasari e la Chimera. Prospettiva, 8, 4-6.

Panofsky, E., \& Saxl, F. (1932/1933). Classical mythology in medieval art. Metropolitan Museum Studies, 4, $228-280$.

Panofsky, P. (1962). The Neoplatonic movement and Michelangelo. In E. Panofsky (Ed.), Studies in iconology: Humanistic themes in the art of the Renaissance (pp. 171-230). New York: Harper and Row.

Passignat, E. (2007). Vasari e i Ragionamenti in Palazzo Vecchio (Vasari and the dialogues in the Old Palace). Ricerche di Storia dell'Arte, 91-92, 115-128.

Passignat, E. (2009a). Cosimo I, Vasari, Palazzo Vecchio e la censura ecclesiastica (Cosimo I, Vasari, Old Palace and the religious censorship). Ricerche di Storia dell'Arte, 98, 67-79.

Passignat, E. (2009b). Le vol de Mercure: Résurgences du Mercure de Jean de Bologne sous la Révolution et l'Empire (The flight of Mercury: Resurgence of Gianbologna's Mercury under the revolution and the empire). Histoire de L'art, 64, 71-83.

Passignat, E. (2013). Des frises, des emblems, des festoons, des grotesques: Giorgio Vasari et le cycle décorative du Palazzo Vecchio à Florence. In R. Dekoninck et al. (Eds.), Questions d'ornements: XVe-XVIIIe siècles (pp. 252-265). Turnhout: Brepols Publisher.

Passignat, E. (2014). The order, the itinerary, the beholder: Considerations on some aspects of the Ragionamenti del Sig. Cavalier Giorgio Vasari. In M. W. Gahtan (Ed.), Giorgio Vasari and the birth of the museum (pp. 151-163). Burlington, VT: Ashgate Publishing Company.

Passignat, E. (2019). Commentary on Giorgio Vasari, Vita di Cristofano Gherardi, detto Doceno, dal Borgo San Sepolcro, pittore. In E. Mattioda (Ed.), Giorgio Vasari, Le vite de’ più eccellenti pittori, scultori e architettori (Vol. 4). Alessandria: Edizioni Dell'Orso.

Pedersen, O. (1985). In quest of Sacrobosco. Journal of the History of Astronomy, 16, 175-221.

Phillips, J. G. (1955). Early Florentine designers and engravers Maso Finiguerra, Baccio Baldini, Antonio Pollaiuolo, Sandro Botticelli, Francesco Rosselli. Cambridge, MA: Harvard University Press.

Place, R. M. (2005). The tarot: History, symbolism and divination. New York: Penguin.

Praz, M. (1947/1964). Studies in the seventeenth century imagery (Vols. 2). London/Rome: Phaidon.

Praz, M. (2014). Studi sul concettismo: Emblema, impresa, epigramma, concetto (Studies on concetism: Emblem, impresa, epigram, conceit, M. Maggi, Ed.). Milan: Aesthetica. 
Reid, J. D. (1993). Oxford Guide to classical mythology in the arts. Oxford: Oxford University Press.

Ribeiro, L. (2015). The Children of Mercury: The image of the artist and the scientist in medieval astrological texts and iconography. In M. A. Miranda and A. M. Caveo (Eds.), Portuguese studies on medieval illuminated manuscripts. Turnhout: Brepols Publisher.

Ripa, C. (1593). Iconologia overo descrittione dell'imagini universali cavate dall'antichita et da altri luoghi. Rome: Gio. Gigliotti.

Ripa, C. (1603). Iconologia. Rome: Lepide Faeij.

Ripa, C. (1971). Iconologia. New York: Dover.

Roob, A. (1997). The hermetic museum: Alchemy and mysticism. London: Taschen.

Rubin, P. L. (1995). Giorgio Vasari: Art and history. New Haven: Yale University Press.

Russell, E. (1981). Alciati’s emblems in Renaissance France. Renaissance Quarterly, 34, 540-549.

Salaman, C., van Oyen, D., Wharton, W. D., \& Mahe, J. P. (2004). The way of Hermes: New translation of the corpus Hermeticum and definitions of Hermes Trismegistus to Asclepius. Rochester, VT: Inner Traditions.

Saxl, F. (1919). Probleme der Planetenkinderbilder (The problem of the Children of the Planets). Leipzig: E. A. Seemann.

Saxl, F. (1938). The literary sources of the Finiguerra Planets. The Journal of the Warburg Institute, 2(1), 72-74.

Schaefer, S. (1976). The studiolo of Francesco I de’ Medici in the Palazzo Vecchio (Ph.D. dissertation, Bryn Mawr College).

Scott, W., \& Ferguson, A. S. (1936). Hermetica, the ancient Green and Latin writings which contain religious or philosophic teaching ascribe to Hermes Trimegistus. Oxford: Clarendon Press.

Seznec, J. (1972). The survival of the Pagan Gods. Princeton: Princeton University Press.

Shackford, M. (1923). Three magi in Florence: An aspect of the Renaissance. Studies in Philology, 20, 377-387.

Shackford, M. (1923). Three magi in Florence: An aspect of the renaissance. Studies in Philology, 20, 377-387. Retrieved September 10, 2019, from https://www.jstor.org/stable/4171869

Slavenburg, J. (2012). The Hermetic link: From the secret tradition to modern thought. Lake Worth, FL: Ibis Press.

Staley, J. E. (1906). The guilds of Florence. London: Methuen \& Co.

Stefani, C. (1990). Cesare Ripa: New biographical evidence. Journal of the Warburg and Courtauld Institutes, 53, 307-312.

Thorndike, L. (1949). The sphere of Sacrobosco. Retrieved August 15, 2019, from http://www.esotericarchives.com/solomon/sphere.htm

Tinagli, P. (2000). The identity of the prince: Cosimo I de’ Medici, Giorgio Vasari and the Ragionamenti. In M. Rogers (Ed.), Fashioning identities in Renaissance art Aldershot (pp. 189-196). UK: Ashgate.

Tinagli, P. (2001). Claiming a place in history: Giorgio Vasari’s ragionamenti and the primacy of the Medici. In K. Eisenbichler (Ed.), The cultural politics of Duke Cosimo I de’ Medici (pp. 63-76). Aldershot, UK: Ashgate.

Trottein, G. (1993). Les Enfants de Venus: Art et Astrologie à la Renaissance (The children of Venus: Art and astrology in the Renaissance). Paris: Lagune.

Van Veen, H. T. (2006). Cosimo I de' Medici and his self-representation in Florentine art and culture. Cambridge: Cambridge University Press.

Van Veen, H. T. (2014). Virtual guided museum tours: Vasari’s I Ragionamenti and Cosimo Bartoli, Ragionamenti Accademici. In M. W. Gahtan (Ed.), Giorgio Vasari and the birth of the museum (pp. 163-177). Burlington, VT: Ashgate Publishing Company.

Vasari, G. (1550). Le Vite de’ piú eccellenti architetti, pittori, et scultori Italiani, da Cimabue insino a' tempi nostri (The lives of the most excellent Italian architects, painters and sculptors, from Cimabue until our time). Florence: Lorenzo Torrentino.

Vasari, G. (1568). Le Vite de’ piú eccellenti, pittori, architetti et scultori Italiani, da Cimabue insino a' tempi nostri (The lives of the most excellent Italian painters, architects and sculptors, from Cimabue until our time). Florence: Fillippo Giunti.

Vasari, G. (1588). Ragionamenti del sig. Caualiere Giorgio Vasari ... sopra le inuentioni da lui dipinte in Firenze nel Palazzo di loro Altezze Serenissime ... Insieme con la inuentione della pittura da lui cominciata nella cupola (The dialogues of Giorgio Vasari ... about his inventions in Florence in the palace of the noble rulers ... together with the inventions of his began paintings for the dome). Florence: Filippo Giunti.

Vernant, J. P. (2001). The universe, the Gods and men. New York: Harper Collins Publishers.

Voss, A. (Ed.). (2006). Marsilio Ficino. Berkeley, CA: North Atlantic Books.

Wallace, W. E. (1997). Michelangelo’s Risen Christ. The Sixteenth Century Journal, 28(4), 1251-1280.

Warburg, A. (1969). Gesammelte Schriften (Vols. 2). Nendel, Leichtenstein: Kraus Reprint.

Weisbach, W. (1919/2010). Trionfi. Berlin: Grote/Nabu Press. 
Weiss, R. (1969). The Renaissance discovery of classical antiquity. Oxford: Oxford University Press.

Whitfield, P. (2001). Astrology: A history. New York: Harry N. Abrams Inc.

Williams, B. (1994). A Renaissance tarot. Stamford, CT: Games Systems.

Wittkower, R. M. (1963). Born under Saturn. New York: Random House.

Zucker, M. J. (1993). The planets. In The illustrated Bartsch, the early Italian masters (Vol. 24, Commentary Part I). Norwalk, CT: Abaris Books. 